JOURNAL OF SYNCHROTRON RADIATION

ISSN 1600-5775

Received 6 September 2021

Accepted 2 November 2021

Edited by S. Wang, Soochow University, People's Republic of China

Keywords: $\mathrm{U}^{\mathrm{VI}}$; uranium; actinides; ettringite; hydrotalcite.

Supporting information: this article has supporting information at journals.iucr.org/s

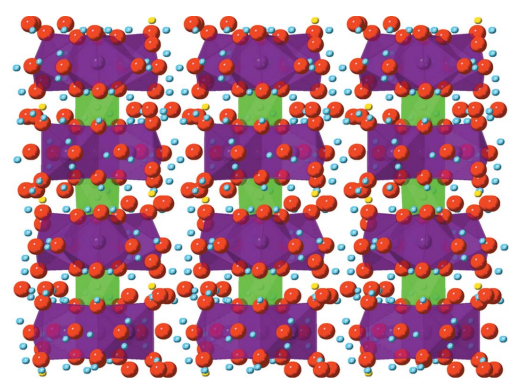

\section{Spectroscopic evaluation of $\mathrm{U}^{\mathrm{V} \mathrm{I}}$-cement mineral interactions: ettringite and hydrotalcite}

\author{
Antonia S. Yorkshire, ${ }^{a}$ Martin C. Stennett, ${ }^{a}$ Brant Walkley, ${ }^{\text {a,b }}$ Sarah E. O'Sullivan, \\ Lucy M. Mottram, ${ }^{a}$ Daniel J. Bailey, ${ }^{a}$ John L. Provis, ${ }^{a}$ Neil C. Hyatt ${ }^{\mathrm{a}}$ and \\ Claire L. Corkhill ${ }^{\mathrm{a} *}$
}

ammobilization Science Laboratory, Department of Materials Science and Engineering, University of Sheffield,
Sheffield S1 3JD, United Kingdom, and ${ }^{\mathbf{b}}$ Sustainable Materials at Sheffield, Department of Chemical and Biological
Engineering, University of Sheffield, Sheffield, United Kingdom. *Correspondence e-mail: c.corkhill@sheffield.ac.uk

Portland cement based grouts used for radioactive waste immobilization contain high replacement levels of supplementary cementitious materials, including blast-furnace slag and fly ash. The minerals formed upon hydration of these cements may have capacity for binding actinide elements present in radioactive waste. In this work, the minerals ettringite $\left(\mathrm{Ca}_{6} \mathrm{Al}_{2}\left(\mathrm{SO}_{4}\right)_{3}(\mathrm{OH})_{12} \cdot 26 \mathrm{H}_{2} \mathrm{O}\right)$ and hydrotalcite $\left(\mathrm{Mg}_{6} \mathrm{Al}_{2}(\mathrm{OH})_{16} \mathrm{CO}_{3} \cdot 4 \mathrm{H}_{2} \mathrm{O}\right)$ were selected to investigate the importance of minor cement hydrate phases in sequestering and immobilizing $\mathrm{U}^{\mathrm{VI}}$ from radioactive waste streams. $\mathrm{U} L_{\mathrm{III}}$-edge $\mathrm{X}$-ray absorption spectroscopy (XAS) was used to probe the $\mathrm{U}^{\mathrm{VI}}$ coordination environment in contact with these minerals. For the first time, solid-state ${ }^{27} \mathrm{Al}$ magic angle spinning nuclear magnetic resonance (MAS-NMR) spectroscopy was applied to probe the $\mathrm{Al}$ coordination environment in these $\mathrm{U}^{\mathrm{VI}}$-contacted minerals and make inferences on the $\mathrm{U}^{\mathrm{VI}}$ coordination, in conjunction with the X-ray spectroscopy analyses. The $\mathrm{U} L_{\mathrm{III}}$-edge XAS analysis of the $\mathrm{U}^{\mathrm{VI}}$-contacted ettringite phases found them to be similar (> 70\%) to the uranyl oxyhydroxides present in a mixed becquerelite/metaschoepite mineral. Fitting of the EXAFS region, in combination with ${ }^{27} \mathrm{Al}$ NMR analysis, indicated that a disordered Ca- or Al-bearing $\mathrm{U}^{\mathrm{VI}}$ secondary phase also formed. For the $\mathrm{U}^{\mathrm{VI}}$-contacted hydrotalcite phases, the XAS and ${ }^{27} \mathrm{Al}$ NMR data were interpreted as being similar to uranyl carbonate, that was likely Mg-containing.

\section{Introduction}

Cementitious binders are used extensively in radioactive waste management. In particular, intermediate- and low-level radioactive waste (ILW and LLW, respectively) are generally suitable for cementitious encapsulation as they are non-heatgenerating; in the UK these are encapsulated using cement blends with high replacement levels of Portland cement (PC) by supplementary cementitious materials ( $\mathrm{SCMs}$ ), including blast-furnace slag (BFS) and fly ash (FA) (Ojovan \& Lee, 2005; Batchelor, 2006). However, ILW streams in particular may still contain measurable radioactivity, some of which will arise from the presence of actinides (Nuclear Decommissioning Authority, 2019). It is, therefore, imperative that steps are taken to understand the fundamental interactions of actinides with cement materials.

Until recently in the UK, once $\mathrm{UO}_{2}$ fuel had been used within a nuclear reactor, it was reprocessed to separate the usable $\mathrm{U}$ and $\mathrm{Pu}$ (to recycle into new fuel) from highly active fission products. The fuel cladding, when separated from the $\mathrm{UO}_{2}$ fuel, is encapsulated in a BFS:PC cement grout (Radioactive Waste Management, 2016). The recovered U is treated 
further for fuel fabrication; however, a large surplus of depleted $\mathrm{U}$ remains. One of the options for management of this material, comprising ${ }^{238} \mathrm{UO}_{3}$ and ${ }^{238} \mathrm{U}_{3} \mathrm{O}_{8}$ powders, is encapsulation within a cement, or mixing with concrete to form a depleted uranium aggregate (DUAGG) which could potentially be used to line vaults in a geological disposal facility (Nuclear Decommissioning Authority, 2014; Radioactive Waste Management, 2016). In these scenarios, cement grout will therefore come into direct contact with U-bearing material. Pu-contaminated materials (PCM) arising from fuel reprocessing operations are immobilized in a FA:PC grout (Nuclear Decommissioning Authority, 2013). Since the primary decay product of $\mathrm{Pu}$ is $\mathrm{U}$, cements that encapsulate PCM will, in the future, also contain U isotopes.

In hardened PC blended with SCMs, the microstructure is dominated by a $\mathrm{Ca}$ - and Si-rich binder phase known as a calcium-silicate-hydrate phase ('C-S-H'). Studies to understand the interaction of $\mathrm{U}$ with cement materials have therefore predominantly been focused on $\mathrm{U}^{\mathrm{VI}}$ (aq) interactions with $\mathrm{C}-\mathrm{S}-\mathrm{H}$ phases, demonstrating good $\mathrm{U}^{\mathrm{VI}}$ uptake and/or secondary $\mathrm{U}^{\mathrm{VI}}$ phase precipitation (Wieland et al., 2010; Harfouche et al., 2006). However, within cement matrices, other minor cement hydrate phases can form in conjunction with the $\mathrm{C}-\mathrm{S}-\mathrm{H}$ binder phase, and studies considering the importance of these phases for actinide immobilization are less extensive. Given that alkaline $\mathrm{pH}$ ranges will prevail under cementitious conditions, aqueous $\mathrm{U}$ speciation will be dominated by uranyl hydroxides [i.e. $\mathrm{UO}_{2}(\mathrm{OH})_{x}{ }^{y-}$ ] (Sutton $e t$ al., 2003) and interlayer anion-exchange mechanisms may be conceivable for $\mathrm{U}^{\mathrm{VI}}$ uptake.

Ettringite $\left(\mathrm{Ca}_{6} \mathrm{Al}_{2}\left(\mathrm{SO}_{4}\right)_{3}(\mathrm{OH})_{12} \cdot 26 \mathrm{H}_{2} \mathrm{O} ; \mathrm{AFt}-\mathrm{SO}_{4}\right)$ is the tri-sulfate phase that forms in $\mathrm{PC}$ as a result of hydration of the tri-calcium aluminate $\left(3 \mathrm{CaO} \cdot \mathrm{Al}_{2} \mathrm{O}_{3}\right)$ clinker phase in the presence of gypsum $\left(\mathrm{CaSO}_{4} \cdot 2 \mathrm{H}_{2} \mathrm{O}\right)$ (Bullard et al., 2011); gypsum is added to cement clinker during production (Hewlett \& Liska, 2019). Ettringite can also form in blends containing BFS or FA, to a certain extent (Lothenbach et al., 2011). The channel-like structure of ettringite, formed by columns of $\mathrm{Al}$ hydroxide and $\mathrm{Ca}$ hydroxide polyhedra that incorporate sulfate $\left(\mathrm{SO}_{4}{ }^{2-}\right)$ anions [see Figs. $1(a)$ and $1(b)$ ] (Goetz-Neunhoeffer \& Neubauer, 2006; Clark et al., 2008), shows potential for anion-exchange and incorporation within its structure. This has been demonstrated previously for anionic radionuclide species, such as pertechnetate $\left(\mathrm{Tc}^{\mathrm{VII}} \mathrm{O}_{4}{ }^{-}\right)$, which exchanges in for sulfate in the ettringite channels (Saslow et al., 2020). Hydrotalcite-type phases (e.g. $\left.\mathrm{Mg}_{6} \mathrm{Al}_{2}(\mathrm{OH})_{16} \mathrm{CO}_{3} \cdot 4 \mathrm{H}_{2} \mathrm{O}\right)$ have been observed to form extensively in cement blends with high BFS contents, and to some extent in those containing FA, as a result of their high $\mathrm{Al}$ and moderate $\mathrm{Mg}$ content (Lothenbach et al., 2011; Richardson \& Groves, 1992). Hydrotalcite phases have a layered double hydroxide (LDH) structure [see Fig. 1(c)], an assemblage that may show good ion-exchange properties (Wijitwongwan et al., 2019), as previously demonstrated for interlayer anions such as chloride $\left(\mathrm{Cl}^{-}\right)$and carbonate $\left(\mathrm{CO}_{3}{ }^{2-}\right)$ (Ke et al., 2017). However, studies using noncementitious $\mathrm{Zn}, \mathrm{Al}$-based carbonate LDHs have demon- strated a decrease in $\mathrm{U}^{\mathrm{VI}}$ uptake at $\mathrm{pH}$ values above $\sim 7$, coinciding with a release of carbonate interlayer anions into solution and resulting in $\mathrm{U}^{\mathrm{VI}}$-carbonate aqueous complexation (Pshinko et al., 2013). Therefore, carbonate-type hydrotalcite LDH phases that form in cement matrices (and thus at higher $\mathrm{pH}$ values) may show potential for capture of $\mathrm{U}^{\mathrm{VI}}$ complexes by surface sorption or secondary phase formation, rather than structural incorporation.

In this study, ettringite and hydrotalcite phases were synthesized and contacted with aqueous $\mathrm{U}^{\mathrm{VI}}$. The local chemistry and coordination of the secondary $\mathrm{U}^{\mathrm{VI}}$ phases

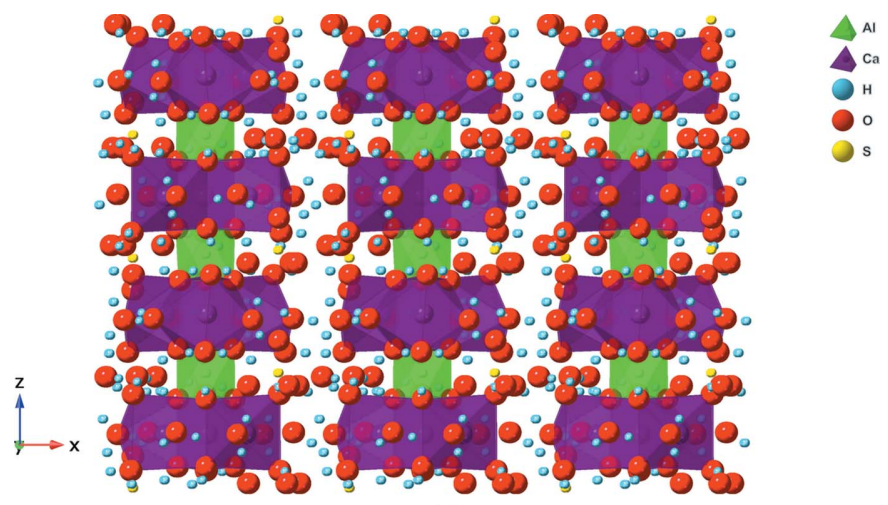

(a)
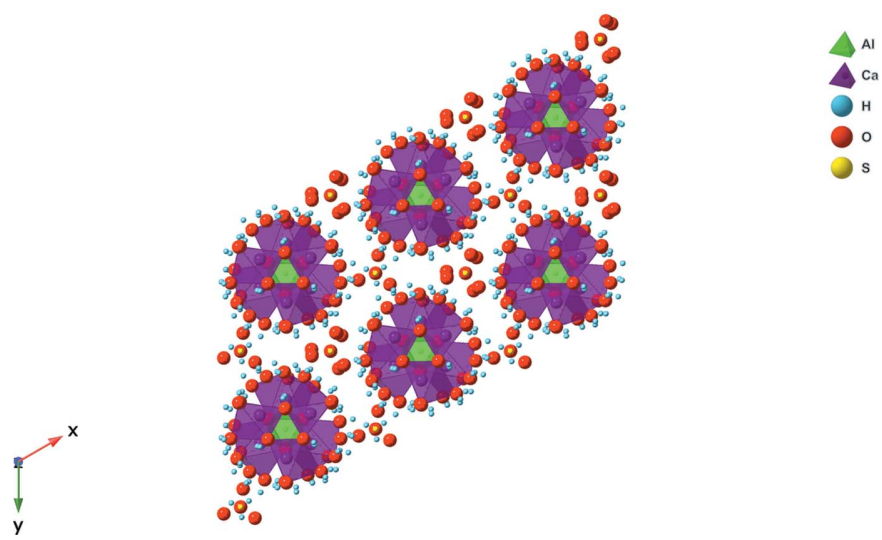

(b)
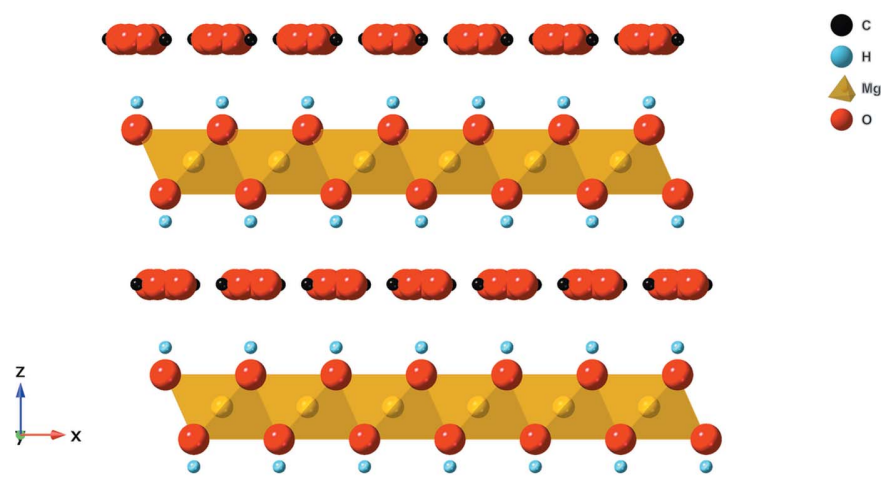

(c)

Figure 1

Representation of the ettringite crystal structure shown down the $y(b)$ axis [panel $(a)$ ] and the $z(c)$ axs [panel $(b)$ ] (Goetz-Neunhoeffer \& Neubauer, 2006). Panel (c) shows a 'cross-sectional' view of the hydrotalcite LDH structure shown down the $y(b)$ axis (Radha et al., 2007), where $\mathrm{Mg}=\mathrm{Mg}$ or Al. Not to scale. 
formed in, or in conjunction with, ettringite and hydrotalcite minerals were probed using $\mathrm{U} L_{\mathrm{III}}$-edge $\mathrm{X}$-ray absorption spectroscopy (XAS). Characterization of the structural modification induced in ettringite and hydrotalcite minerals as a consequence of $\mathrm{U}^{\mathrm{VI}}$ incorporation was also performed using solid-state ${ }^{27} \mathrm{Al}$ magic angle spinning nuclear magnetic resonance (MAS-NMR) spectroscopy.

\section{Experimental methods}

\subsection{Materials}

ACS-grade $\quad \mathrm{NaOH} \quad(\geq 97.0 \%), \quad \mathrm{Na}_{2} \mathrm{CO}_{3} \quad(99 \%)$, $\mathrm{Al}\left(\mathrm{NO}_{3}\right)_{3} \cdot 9 \mathrm{H}_{2} \mathrm{O}(\geq 98 \%), \mathrm{Mg}\left(\mathrm{NO}_{3}\right)_{2} \cdot 6 \mathrm{H}_{2} \mathrm{O}(99 \%), \mathrm{Ca}(\mathrm{OH})_{2}$ $(\geq 97.0 \%)$ and $\mathrm{Al}_{2}\left(\mathrm{SO}_{4}\right)_{3} \cdot 16 \mathrm{H}_{2} \mathrm{O}(\geq 98 \%)$, supplied by Sigma Aldrich, were used for the synthesis of cement minerals. Ultra high quality deionized water (referred to as UHQ hereafter) was used for all aqueous solutions and suspensions, generated by filtration to achieve a resistivity measurement of $18.18 \mathrm{M} \Omega \mathrm{cm}^{-1}$. All weighing of precursors was carried out under ambient conditions on the benchtop, but mixing, filtration and storage were carried out under an $\mathrm{N}_{2}$ atmosphere to prevent carbonation of cement minerals, unless otherwise stated.

\subsection{Ettringite and hydrotalcite synthesis}

A novel synthesis method was devised for producing ettringite, using hydrothermal treatment, developed from methods previously reported in the literature (Goetz-Neunhoeffer et al., 2006; Yang \& Guo, 2014). The stoichiometry of the reaction was based on equation (1):

$$
\begin{gathered}
6 \mathrm{Ca}(\mathrm{OH})_{2}+\mathrm{Al}_{2}\left(\mathrm{SO}_{4}\right)_{3}+\mathrm{H}_{2} \mathrm{O}(\text { excess }) \rightarrow \\
\mathrm{Ca}_{6} \mathrm{Al}_{2}\left(\mathrm{SO}_{4}\right)_{3}(\mathrm{OH})_{12} \cdot 26 \mathrm{H}_{2} \mathrm{O} .
\end{gathered}
$$

$\mathrm{Ca}(\mathrm{OH})_{2}$ was added to an aqueous solution of $\mathrm{Al}_{2}\left(\mathrm{SO}_{4}\right)_{3}$ in Ar-degassed UHQ in stoichiometric amounts and the solution-suspension was mixed well before it was poured into Teflon-lined Parr vessels which were sealed, tightened and placed into a heating block for 1 week at $180^{\circ} \mathrm{C}$ (not under $\mathrm{N}_{2}$ atmosphere). After reaction, the resulting solids were removed from the Parr vessels and dried at $35^{\circ} \mathrm{C}$ for $\sim 24 \mathrm{~h}$ before being ground to a fine powder for characterization; they were subsequently stored under $\mathrm{N}_{2}$.

A pH-controlled solution mixing method was used to synthesize hydrotalcite, similar to the method reported elsewhere (Aimoz et al., 2012). A solution of $1 M \mathrm{Mg}\left(\mathrm{NO}_{3}\right)_{3} / 1 M$ $\mathrm{Al}\left(\mathrm{NO}_{3}\right)_{3}$ was added dropwise to a $1 M \mathrm{Na}_{2} \mathrm{CO}_{3}$ solution, and the $\mathrm{pH}$ was maintained at $>\mathrm{pH} 11.0$ with additions of $0.5 \mathrm{M}$ $\mathrm{NaOH}$ where necessary. This method precipitated an Mg- and Al-containing LDH with a 'carbonate interlayer'. The precipitated solid was filtered gravitationally using a Whatman-542ashless filter paper and washed with a minimum of $10 \mathrm{ml}$ UHQ to ensure removal of residual salts and carbonates. The powder was dried under ambient atmosphere at $35^{\circ} \mathrm{C}$ for $\sim 24 \mathrm{~h}$ before being ground into a fine powder for characterization; it was subsequently stored under $\mathrm{N}_{2}$.
Table 1

\begin{tabular}{|c|c|c|c|}
\hline Mineral & $\begin{array}{l}\mathrm{U}^{\mathrm{VI}} \\
\text { aqueous } \\
\text { concentration } \\
(\mathrm{m} M)\end{array}$ & $\begin{array}{l}\text { Target } U^{\mathrm{VI}} \\
\text { loading on } \\
\text { mineral } \\
\text { phase (ppm) }\end{array}$ & $\begin{array}{l}\text { Sample } \\
\text { designation }\end{array}$ \\
\hline Ettringite & 0.5 & 4800 & Ettringite $0.5 \mathrm{~m} M \mathrm{U}^{\mathrm{VI}}$ \\
\hline Ettringite & 10 & 95000 & Ettringite $10 \mathrm{~m} M \mathrm{U}^{\mathrm{VI}}$ \\
\hline Hydrotalcite & 0.5 & 4800 & Hydrotalcite $0.5 \mathrm{~m} M \mathrm{U}^{\mathrm{VI}}$ \\
\hline Hydrotalcite & 10 & 95000 & Hydrotalcite $10 \mathrm{~m} M \mathrm{U}^{\mathrm{VI}}$ \\
\hline
\end{tabular}

Details of the $\mathrm{U}^{\mathrm{VI}}$-contacted cement mineral samples.

\section{3. $U^{\mathrm{VI}}$ contact experiments}

Aqueous $\mathrm{U}^{\mathrm{VI}}$ contact experiments were performed on both ettringite and hydrotalcite cement mineral phases. The dry powders were added to aqueous solutions of $\mathrm{U}^{\mathrm{VI}}$ in UHQ [as uranyl nitrate; $\mathrm{UO}_{2} \mathrm{NO}_{3}(\mathrm{aq})$ ] at concentrations of both $0.5 \mathrm{~m} M$ ('borderline trace') and $10 \mathrm{mM}$ ('elevated'), achieving a solidsto-liquid ratio of $25 \mathrm{~g} \mathrm{l}^{-1}$. The suspensions were mixed on a rotary shaker for $48 \mathrm{~h}$, after which time they were filtered through $0.22 \mu \mathrm{m}$ cellulose filters. The solution $\mathrm{pH}$ values were measured before the solutions were acidified and prepared for ICP-OES (inductively coupled plasma optical emission spectrometry) analysis (ThermoFisher iCAP Duo 6300) to measure $\mathrm{U}, \mathrm{Ca}, \mathrm{S}, \mathrm{Al}$ or $\mathrm{Mg}$ concentrations. The remaining solids were dried at ambient temperature, under $\mathrm{N}_{2}$, for at least $24 \mathrm{~h}$ before preparation for X-ray diffraction (XRD), XAS and MAS-NMR spectroscopy. Table 1 displays the sample designations, and the target $\mathrm{U}^{\mathrm{VI}}$ loading per mineral phase.

2.3.1. Geochemical modelling estimations. Geochemical modelling was performed using the Phreeqc Interactive 3.4.012927 software and the Lawrence Livermore National Laboratory thermodynamic database, to estimate the saturation index (SI) of mineral phases likely to form in aqueous solution under the experimental conditions of the $\mathrm{U}^{\mathrm{VI}}$ contact studies. The results from ICP-OES analyses and the solution $\mathrm{pH}$ values were used for the model input for $\mathrm{Ca}, \mathrm{S}, \mathrm{Al}$ or $\mathrm{Mg}$, while the $\mathrm{U}^{\mathrm{VI}}$ concentration corresponded to either the $0.5 \mathrm{~m} M$ or $10 \mathrm{~m} M$ concentration in the initial solution.

\subsection{Solid-state analysis}

XRD measurements of all ettringite and hydrotalcite phases were performed both before and after $\mathrm{U}^{\mathrm{VI}}$ contact experiments, using a Bruker D2 desktop instrument. Powders were compressed into a $10 \mathrm{~mm}$-diameter recess on a lowbackground $\mathrm{Si}(111)$ plate in a PMMA holder. For Ucontaining samples (i.e. after $\mathrm{U}^{\mathrm{VI}}$ contact) the compressed powder was covered with an acetate film held in place with a small amount of PVA adhesive, in accordance with alphapowder handling protocols. Measurements were taken between 5 and $50^{\circ} 2 \theta$ for ettringite samples and 5 and $70^{\circ} 2 \theta$ for hydrotalcite samples. The counting time was $1 \mathrm{~s}$ per step, in increments of $0.02^{\circ} 2 \theta$ with a $1 \mathrm{~mm}$ divergence slit.

$\mathrm{U} L_{\mathrm{III}}$-edge $(17166 \mathrm{eV})$ XAS was performed at Diamond Light Source (DLS) (on beamline B18) to obtain information in the XANES and EXAFS regions of each of the $\mathrm{U}^{\mathrm{VI}}$ - 
Table 2

U-bearing ceramic and mineral phases measured by $\mathrm{U} L_{\mathrm{III}}$-edge XAS.

\begin{tabular}{lll}
\hline & $\begin{array}{l}\text { Synthetic (S) } \\
\text { or natural }(\mathrm{N})\end{array}$ & $\begin{array}{l}\text { Approximate } \\
\text { U oxidation }\end{array}$ \\
state
\end{tabular}

$\dagger \mathrm{UO}_{2}$ was used for energy alignment and determination of $S_{0}{ }^{2}$. $\ddagger$ This standard was determined to be a mixture of two phases upon XRD analysis. Both are stated (Yorkshire, 2020).

contacted ettringite and hydrotalcite samples, as well as for a suite of standard U-bearing mineral and ceramic phases (see Table 2), in transmission mode. The amount of material required to allow for transmission measurement at one absorption length was calculated using the Hephaestus program (Ravel \& Newville, 2005); for $\mathrm{U}^{\mathrm{VI}}$-contacted mineral phases this was estimated based on the known general chemical formula of the mineral phases and an assumption of $100 \% \mathrm{U}^{\mathrm{VI}}(\mathrm{aq})$ uptake from solution. The accurately weighed powders were pressed into pellets using a polyethylene glycol (PEG) binder ( $\sim 50 \mathrm{mg})$ to allow for mechanical stability, pressed at $\sim 1$ tonne for $\sim 1$ min.

A Si(111) monochromator with beam collimation (achieved using a Cr- and Pt-coated Si mirror) was utilized (DiazMoreno et al., 2018). An Y foil was used in the reference channel for monochromator calibration. The Athena program was used for post-processing and normalization of data (Ravel \& Newville, 2005). Data calibration was performed by assigning the first inflection point of the derivative energy spectrum (i.e. $E_{0}$ ) for the $\mathrm{Y}$ foil in the reference channel as $17038 \mathrm{keV}$ ( $K$ edge) (Bearden \& Burr, 1967). The value of $E_{0}$ for each data set was then assigned to the position of the maximum inflection point of its derivative energy spectrum.

Linear combination fitting analysis was applied to the XANES region of the spectra using the Athena software. A combination of any two of the considered phases (Table 2) was allowed to be fitted within the region of -20 and $+30 \mathrm{eV}$ from the position of $E_{0}$. The value of $\Delta E$ for each phase fit was recorded. The 'best fit' for each sample was chosen based on a combination of prior knowledge of the system deduced from XRD, NMR, geochemical modelling estimations, in addition to $R$-factor and $\chi^{2}$ values.

The Artemis program was used for the generation of scattering pathways and fitting of models for the EXAFS region (Ravel \& Newville, 2005). In Athena, prior to this, the fitting window for the Fourier transform of $k$ space into $R$ space was selected where the signal in $k$ space was approximately equal to 0 , using a Hanning window $(\mathrm{d} k=0)$, before being imported into Artemis. Scattering paths were generated using FEFF
(Ravel \& Newville, 2005) calculations of appropriately selected CIF files as the input, using prior knowledge of the system determined from XRD and geochemical modelling estimations as a starting point. Pathways were fitted between $\sim 1$ and $\sim 5 \AA$ in $R$ space using a Hanning window $(\mathrm{d} R=0)$. $\Delta E$ was allowed to vary as a global parameter. As well as single scattering (SS) pathways, multiple scattering (MS) pathways were considered for $\mathrm{U}-\mathrm{O}_{\mathrm{ax}}-\mathrm{O}_{\mathrm{ax}}$ (linear) or $\mathrm{U}-\mathrm{O}_{\mathrm{ax}}-$ $\mathrm{O}_{\text {eq }}$ (linear) interactions, where applicable (see Section 3.3).

The value of the amplitude reduction factor $\left(S_{0}{ }^{2}\right)$ for a $\mathrm{U}$ absorber measured on beamline B18 (DLS) was determined in the model for $\mathrm{UO}_{2}$ as 0.86 , using pathways generated from the CIF file for $\mathrm{UO}_{2}$ (ICSD No. 160814) (Greaux et al., 2008), and was thereafter fixed in the model for the fitting of all other phases. The first-shell coordination number for $\mathrm{U}^{\mathrm{VI}}$-contacted mineral phases was determined by setting $S_{0}{ }^{2}$ in the model and allowing the product of $\left(N_{X 1} \times S_{0}{ }^{2}\right)$ to vary, where $N_{X 1}$ is the first-shell coordination number.

The $\mathrm{U}^{\mathrm{VI}}$-contacted minerals were also measured by solidstate ${ }^{27} \mathrm{Al}$ MAS-NMR spectroscopy, as well as pure-phase ettringite and hydrotalcite for comparison. Samples were packed into $4 \mathrm{~mm} \mathrm{ZrO}_{2}$ sample rotors and spectra were collected using a Bruker Avance III HD 500 spectrometer at $11.4 \mathrm{~T}$, with a resulting Larmor frequency of $130.32 \mathrm{MHz}$ for ${ }^{27} \mathrm{Al} .{ }^{27} \mathrm{Al}$ chemical shifts were referenced to $\mathrm{Al}\left(\mathrm{NO}_{3}\right)_{3}$ (aq). A magic angle spinning (MAS) rate of $12.5 \mathrm{kHz}$ was applied. Conventional single-pulse experiments were carried out using an optimized pulse length of $1.4 \mu \mathrm{s}$ and recycle delays of $35 \mathrm{~s}$ and $25 \mathrm{~s}$ for ettringite and hydrotalcite systems, respectively. A total of 256 scans were acquired for each sample. Postprocessing of the data was carried out using the TopSpin 4.0.6 software, and data were normalized by integrated area.

\section{Results}

\section{1. $U^{\mathrm{VI}}$ uptake by ettringite and hydrotalcite}

The $\mathrm{pH}$ measurements for the $0.5 \mathrm{~m} M$ and $10 \mathrm{~m} M \mathrm{U}^{\mathrm{VI}}$ solutions both before and after contact with ettringite and hydrotalcite are given in Table 3. The removal of $\mathrm{U}^{\mathrm{VI}}$ from solution (i.e. $\mathrm{U}^{\mathrm{VI}}$ uptake by the solid) as a percentage of $\left[\mathrm{U}^{\mathrm{VI}}\right]_{t=0}$ by both ettringite and hydrotalcite is shown in Fig. 2(a). At both $0.5 \mathrm{~m} M$ and $10 \mathrm{~m} M \mathrm{U}^{\mathrm{VI}}$, ettringite effectively showed complete uptake of $\mathrm{U}^{\mathrm{VI}}$ (>99\%) whereas hydrotalcite showed $\sim 30 \%$ uptake at both $\mathrm{U}^{\mathrm{VI}}$ concentrations. It was concluded that the discrepancy in the uptake between the two mineral phases was due to the significant amount of dissolved carbonate released from the hydrotalcite phases, leading to $\mathrm{U}^{\mathrm{VI}}$-carbonate complex formation in solution, increasing the $\mathrm{U}^{\mathrm{VI}}$ solubility and thus decreasing the amount of $\mathrm{U}^{\mathrm{VI}}$ uptake by the solid phase (Pshinko et al., 2013).

The release of $\mathrm{Ca}, \mathrm{Al}, \mathrm{S}$ or $\mathrm{Mg}$ from ettringite and hydrotalcite into solution is given in Figs. 2(b) and 2(c), respectively. $\mathrm{Ca}$ and $\mathrm{S}$ release from ettringite was shown to increase with increasing $\mathrm{U}^{\mathrm{VI}}$ concentration, thus with a decrease in $\mathrm{pH}$. The release of $\mathrm{Ca}$ was over two times higher after contact with $10 \mathrm{~m} M \mathrm{U}^{\mathrm{VI}}$ compared with $0.5 \mathrm{~m} M \mathrm{U}^{\mathrm{VI}}$ ([Ca] $=\sim 1000 \mathrm{ppm}$ 
Table 3

$\mathrm{pH}$ measurements of uranyl nitrate starting solution and of solutions where uranyl nitrate was mixed with solid cement mineral phases in solution.

The errors represent the standard deviation of triplicate measurements.

\begin{tabular}{ll}
\hline Solution & $\mathrm{pH}$ \\
\hline $0.5 \mathrm{~m} M\left[\mathrm{U}^{\mathrm{VI}}\right]$ solution & $3.6 \pm 0.1$ \\
$10 \mathrm{~m} M\left[\mathrm{U}^{\mathrm{VI}}\right]$ solution & $2.8 \pm 0.0$ \\
Ettringite $0.5 \mathrm{~m} M \mathrm{U}^{\mathrm{VI}}$ & $10.5 \pm 0.2$ \\
Ettringite $10 \mathrm{~m} M \mathrm{U}^{\mathrm{VI}}$ & $9.9 \pm 0.2$ \\
Hydrotalcite $0.5 \mathrm{~m} M \mathrm{U}^{\mathrm{VI}}$ & $10.2 \pm 0.2$ \\
Hydrotalcite $10 \mathrm{~m} M \mathrm{U}^{\mathrm{VI}}$ & $7.8 \pm 0.2$ \\
\hline
\end{tabular}

versus $\sim 450 \mathrm{ppm}$ ), whereas the $\mathrm{S}$ concentration showed a smaller increase $([\mathrm{S}]=\sim 300 \mathrm{ppm}$ versus $\sim 400 \mathrm{ppm})$. For hydrotalcite, the $\mathrm{Mg}$ release was very low in the $0.5 \mathrm{~m} M\left[\mathrm{U}^{\mathrm{VI}}\right]$ solution, at $0.20 \pm 0.02 \mathrm{ppm}$, and was significantly increased in the $10 \mathrm{~m} M \mathrm{U}^{\mathrm{VI}}$ solution, at $36.2 \pm 1.8 \mathrm{ppm}$. This observed leaching was insufficient to significantly alter the minerals, which retained their crystallographic structure (see Section 3.2).

The $\mathrm{Al}$ release in both ettringite and hydrotalcite displayed the opposite behaviour, i.e. the concentrations decreased with increasing $\mathrm{U}^{\mathrm{VI}}$ concentration (i.e. with decreasing $\mathrm{pH}$ ). For hydrotalcite, this could be related to the decrease in $\mathrm{Al}$ solubility with decreasing $\mathrm{pH}$ at the two different $\mathrm{U}^{\mathrm{VI}}$ concentrations ( $\mathrm{pH} \sim 10.2$ compared with $\mathrm{pH} \sim 7.8$ ). For ettringite, this could also be the case to a certain extent, with a $\mathrm{pH}$ decrease from $\sim 10.5$ to $\sim 9.5$; however, the explanation for this could be more complex and requires the justifications of XRD and NMR analyses (see Sections 3.3 and 3.4).

\subsection{Phase analysis before and after $U^{\mathrm{VI}}$ contact}

The concentrations of $\mathrm{Ca}, \mathrm{S}, \mathrm{Al}$ or $\mathrm{Mg}$ released into solution and measured $\mathrm{pH}$ (Table 3) were input modelled using Phreeqc, at $\mathrm{U}^{\mathrm{VI}}$ concentrations of $0.5 \mathrm{mM}(119 \mathrm{ppm})$ and $10 \mathrm{~m} M(2380 \mathrm{ppm})$, to ascertain the thermodynamically feasible $\mathrm{Ca}-, \mathrm{S}-, \mathrm{Al}-, \mathrm{Mg}-$ and/or U-containing saturated phases in the corresponding systems (Fig. 3).

Boehmite and diaspore $(\mathrm{AlO}(\mathrm{OH})$ polymorphs, denoted as 'B' and 'D', respectively), corundum $\left(\mathrm{Al}_{2} \mathrm{O}_{3}\right)$, gibbsite $\left(\mathrm{Al}(\mathrm{OH})_{3}\right)$, metaschoepite $\left(\mathrm{UO}_{3} \cdot 2 \mathrm{H}_{2} \mathrm{O}\right)$ and uranium hydroxide $\left(\mathrm{UO}_{2}(\mathrm{OH})_{2}\right)$ were identified as being saturated in both hydrotalcite- $\mathrm{U}^{\mathrm{VI}}$ systems [Fig. 3(b)]. For the ettringite- $\mathrm{U}^{\mathrm{VI}}$ systems, calcium uranate $\left(\mathrm{CaUO}_{4}\right)$ was additionally identified; however, at the $10 \mathrm{~m} M \mathrm{U}^{\mathrm{VI}}$ concentration, $\mathrm{Al}_{2} \mathrm{O}_{3}$ had a negative saturation index, likely due to the low concentration of $\mathrm{Al}$ measured in solution [Fig. 3(a)]. Although the calcium uranate phase identified in this system is a high-temperature phase (Takahashi et al., 1993), hydrous forms of calcium uranate exist (e.g. $\mathrm{CaU}_{2} \mathrm{O}_{7} \cdot x \mathrm{H}_{2} \mathrm{O}_{(\text {cr })}$ ) and calcium uranate phases are typically solubility limiting for $\mathrm{U} / \mathrm{Ca}$ at high $\mathrm{pH}$ (Finch \& Ewing, 1997; Valsami-Jones \& Ragnarsdöttir, 1997; Sutton et al., 2003; Ding et al., 2016; Ding, 2017; ÇevirimPapaioannou et al., 2018; Yalçıntaş et al., 2019; Adam et al., 2021).
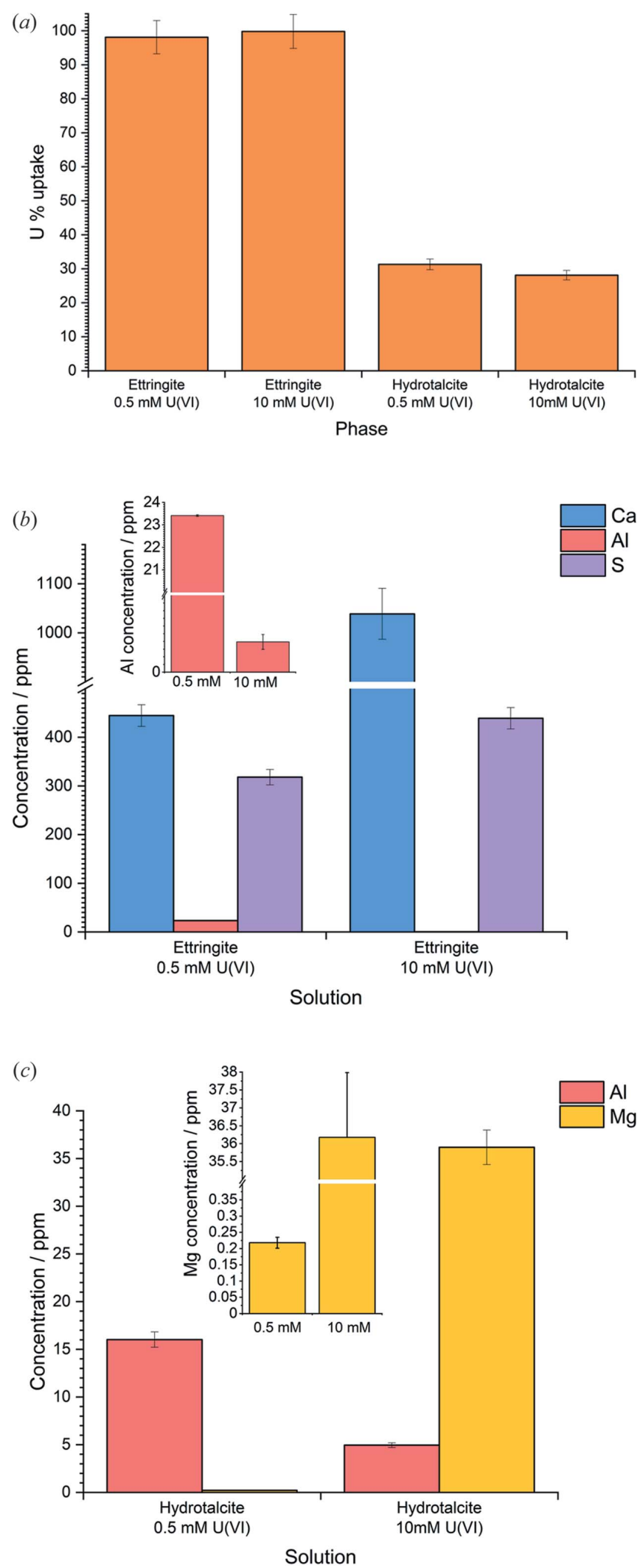

Figure 2

Aqueous elemental analysis of solutions containing $\mathrm{U}^{\mathrm{VI}}$ and cement minerals. (a) $\mathrm{U}^{\mathrm{VI}}$ removal from solution by ettringite and hydrotalcite as a percentage of $\left[\mathrm{U}^{\mathrm{VI}}\right]_{t=0} ;(b) \mathrm{Ca}, \mathrm{Al}$ and $\mathrm{S}$ release from ettringite in contact with $\mathrm{U}^{\mathrm{VI}} ;(c) \mathrm{Al}$ and $\mathrm{Mg}$ release from hydrotalcite in contact with $\mathrm{U}^{\mathrm{VI}}$. Error bars represent one standard deviation of triplicate samples. 


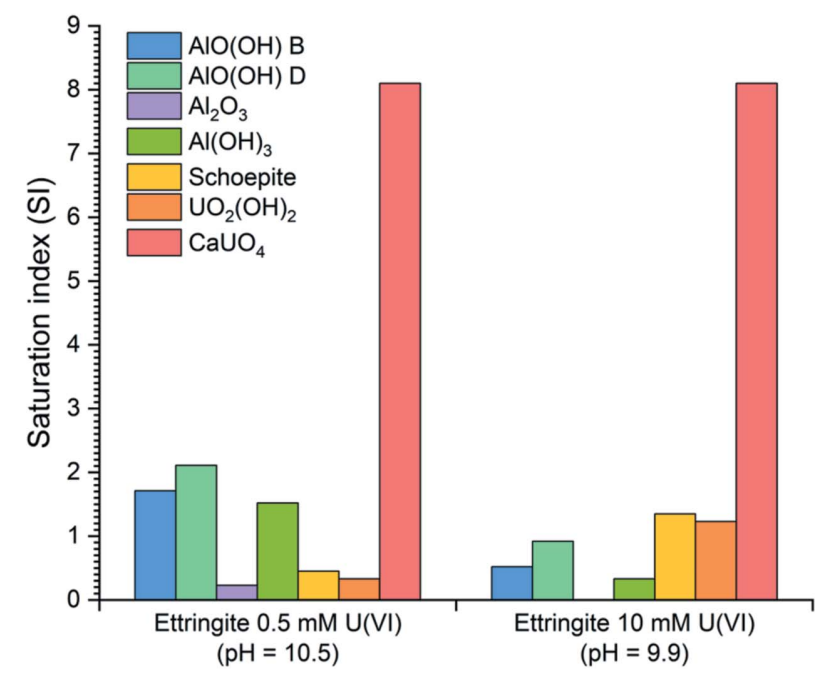

(a)

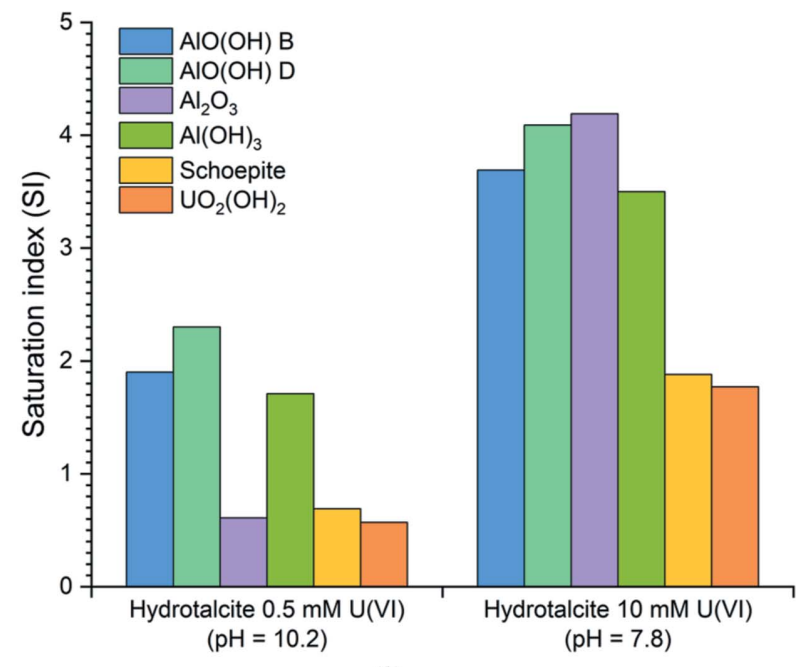

(b)

Figure 3

Geochemical modelling results showing all estimated saturated phases over the experimental $\mathrm{pH}$ range measured for the (a) ettringite and (b) hydrotalcite samples, in contact with $0.5 \mathrm{~m} M \mathrm{U}^{\mathrm{VI}}$ and $10 \mathrm{mM} \mathrm{U}^{\mathrm{VI}}$.

The geochemical modelling predictions were evaluated upon XRD analysis of the $\mathrm{U}^{\mathrm{VI}}$-contacted phases (Fig. 4). The reflections assigned to the originally synthesized ettringite phase [powder diffraction file (PDF) No. 04-013-3691] (GoetzNeunhoeffer et al., 2006) were still present in the samples contacted with $0.5 \mathrm{~m} M$ and $10 \mathrm{~m} M \mathrm{U}^{\mathrm{VI}}$ solution [Fig. 4(a)]. The peak attributed to the reflection of anhydrite $\left[\mathrm{CaSO}_{4}\right.$; PDF No. 00-037-1496 (McMurdie et al., 1986)] at $\sim 25.5^{\circ} 2 \theta$ (denoted 'A') disappeared at both $\mathrm{U}^{\mathrm{VI}}$ concentrations, likely due to the dissolution of anhydrite by the low-pH uranyl nitrate solution. The peaks assigned to gypsum $\left[\mathrm{CaSO}_{4} \cdot 2 \mathrm{H}_{2} \mathrm{O}\right.$; PDF No. 00-033-0311 (Morris et al., 1980); denoted ' $G$ '] decreased in intensity, relative to ettringite, after contact with $0.5 \mathrm{~m} M \mathrm{U}^{\mathrm{VI}}$ but increased in intensity after contact with $10 \mathrm{~m} M \mathrm{U}^{\mathrm{VI}}$, which is unexpected given the corresponding increase in $\mathrm{Ca}$ and $\mathrm{S}$ released to solution. This therefore suggests increased ettringite dissolution in the $10 \mathrm{mM} \mathrm{U}^{\mathrm{VI}}$ solution, compared with gypsum dissolution. The lower

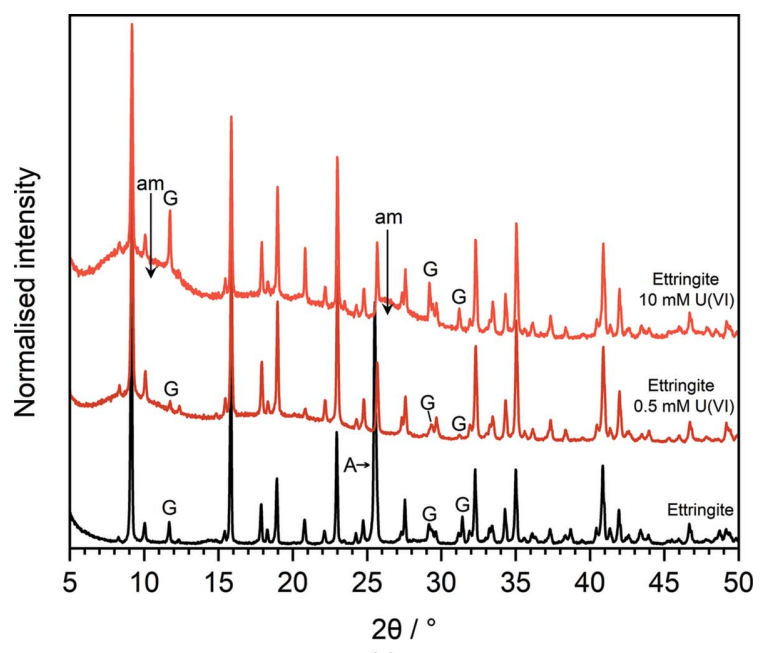

(a)

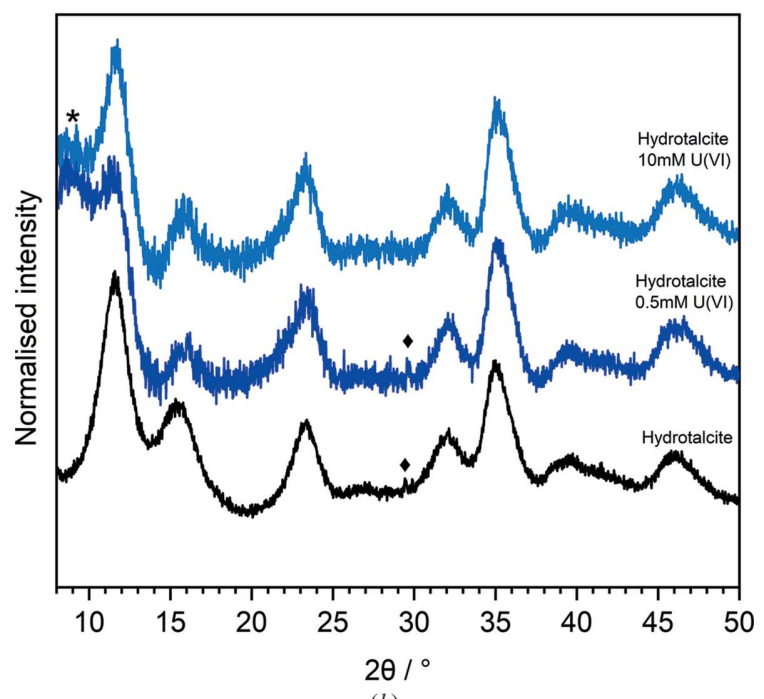

(b)

Figure 4

XRD patterns of $(a)$ ettringite [PDF No. 04-013-3691 (GoetzNeunhoeffer et al., 2006)] and (b) hydrotalcite [PDF No. 01-082-8041 (Taylor, 1973)], before and after contact with $\mathrm{U}^{\mathrm{VI}}$ at $0.5 \mathrm{~m} M$ and $10 \mathrm{~m} M$. $\mathrm{A}=$ anhydrite [CaSO${ }_{4} ;$ PDF No. 00-037-1496 (McMurdie et al., 1986)]; G = gypsum [ $\mathrm{CaSO}_{4} \cdot 2 \mathrm{H}_{2} \mathrm{O}$; PDF No. 00-033-0311 (Morris et al., 1980)]. Diffraction patterns are normalized to the maximum peak intensity in both systems. In (a), regions of diffuse scattering are a result of sample preparation methods for radioactive samples unless denoted by 'am'. In (b), background subtraction was performed on the diffraction patterns to highlight the diffuse diffraction peaks. The black diamond symbol indicates an unidentified phase and the asterisk indicates the background from sample preparation methods that could not be subtracted.

concentration of $\mathrm{Al}$ in the $10 \mathrm{~m} M \mathrm{U}^{\mathrm{VI}}$ solution could, therefore, be explained by the precipitation of a poorly crystalline secondary Al hydroxide phase, potentially indicated by the regions of diffuse scattering observed between $\sim 7-13^{\circ}$ and $\sim 26-30^{\circ} 2 \theta$ (denoted 'am'), that could also be U-containing. Given that $>99 \%$ uptake of $U^{\mathrm{VI}}$ was observed and no other Ucontaining phases were identifiable by XRD, it is certainly plausible that these amorphous regions may arise from a poorly crystalline U-containing phase. ${ }^{27} \mathrm{Al}$ MAS-NMR analysis on these solid phases was used to evaluate these hypotheses (see Section 3.4). 
Table 4

Weighted fraction of signal contributions in the XANES region, determined using linear combination fitting, for $\mathrm{U}^{\mathrm{VI}}$-contacted ettringite and hydrotalcite systems.

\begin{tabular}{|c|c|c|c|c|c|c|c|}
\hline & $\mathrm{U}^{\mathrm{VI}}$ & \multirow[b]{2}{*}{$R$ factor } & \multirow[b]{2}{*}{$\begin{array}{l}\text { Total } \\
\text { weighting }\end{array}$} & \multicolumn{2}{|c|}{ Uranyl phase $\dagger$} & \multicolumn{2}{|c|}{ Uranate phase $\ddagger$} \\
\hline Mineral phase & $\begin{array}{l}\text { concentration } \\
(\mathrm{m} M)\end{array}$ & & & Weight & $\Delta E$ & Weight & $\Delta E$ \\
\hline Ettringite & 0.5 & $4 \times 10^{-4}$ & 1.034 & $0.794(97)$ & $0.3(3)$ & $0.240(22)$ & $0.07(33)$ \\
\hline \multirow[t]{2}{*}{ Hydrotalcite } & 0.5 & $2 \times 10^{-3}$ & 1.000 & $0.933(25)$ & $0.90(7)$ & $0.067(25)$ & $-1.6(1.2)$ \\
\hline & 10 & $5 \times 10^{-4}$ & 1.013 & 0.989 (14) & $-0.12(4)$ & $0.024(13)$ & $-0.8(2.0)$ \\
\hline
\end{tabular}

$\dagger$ Becquerelite/metaschoepite for ettringite and bayleyite/andersonite for hydrotalcite. $\quad$ $\mathrm{CaUO}_{4}$ for ettringite and $\mathrm{MgUO}_{4}$ for hydrotalcite.

The XRD peaks for nanocrystalline hydrotalcite [PDF No. 01-082-8041 (Taylor, 1973)] were maintained on addition of both $0.5 \mathrm{~m} M$ and $10 \mathrm{~m} M \mathrm{U}^{\mathrm{VI}}$ solutions [Fig. 4(b)]. The diffuse nature of these diffraction patterns makes the identification of any low-yield secondary phases challenging; however, there appears to be little to no change in the diffraction pattern on addition of both concentrations of $\mathrm{U}^{\mathrm{VI}}$. In the starting phase a peak at $\sim 29.5^{\circ} 2 \theta$ was partially indexed as boehmite [AlO(OH); PDF No. 01-074-2895 (Bokhimi et al., 2001)]. This phase was also present in the $0.5 \mathrm{~m} M \mathrm{U}^{\mathrm{VI}}$-contacted sample but not in the $10 \mathrm{~m} M \mathrm{U}^{\mathrm{VI}}$-contacted sample. In both the ettringite and hydrotalcite systems, there was no obvious (i.e. XRD observable) identification of the mineral phases indicated by the corresponding geochemical modelling.

\subsection{Local coordination chemistry of $U^{\mathrm{V} \mathrm{I}}$ associated with ettringite and hydrotalcite}

The $\mathrm{U} L_{\mathrm{III}}$-edge energy XANES spectra and $k^{3}$-weighted spectra for the standard U-bearing mineral and ceramic phases and the $\mathrm{U}^{\mathrm{VI}}$-contacted ettringite and hydrotalcite minerals are shown in Figs. 5(a) and 5(b), respectively, along with the percentage composition of XANES signals contributing to the linear combination fits for the $\mathrm{U}^{\mathrm{VI}}$-contacted ettringite and hydrotalcite systems in Fig. 5(c). The results for the weighted component for each linear combination fit are also given in Table 4.

The linear combination fit for the XANES region of the $\mathrm{U}^{\mathrm{VI}}$-contacted ettringite phases did not alter significantly as a function of $\mathrm{U}^{\mathrm{VI}}$ concentration. The XANES signals were comparable largely with those of the mixed becquerelite/ metaschoepite mineral phase, at $\sim 77 \%$ and $\sim 70 \%$ for $0.5 \mathrm{mM}$ and $10 \mathrm{mM} \mathrm{U}^{\mathrm{VI}}$ solutions, respectively. The remainder of the signals showed a contribution similar to that of calcium uranate $\left(\mathrm{CaUO}_{4}\right)$ in both cases. Signal domination from the becquerelite/metaschoepite phase indicates the retention of the uranyl moiety, that may be bonded to $\mathrm{Ca}$, in addition to the co-formation of a calcium uranate type phase.

The linear combination fit for the XANES region of the $\mathrm{U}^{\mathrm{VI}}$-contacted hydrotalcite phases also showed a similar pattern irrespective of $U^{\mathrm{VI}}$ concentration. The majority of the XANES signals were comparable with those of the mixed bayleyite/andersonite phase, at $>90 \%$ for both concentrations of $\mathrm{U}^{\mathrm{VI}}$. The small remainder of the signals were comparable with those of magnesium uranate $\left(\mathrm{MgUO}_{4}\right)$ in both cases. This
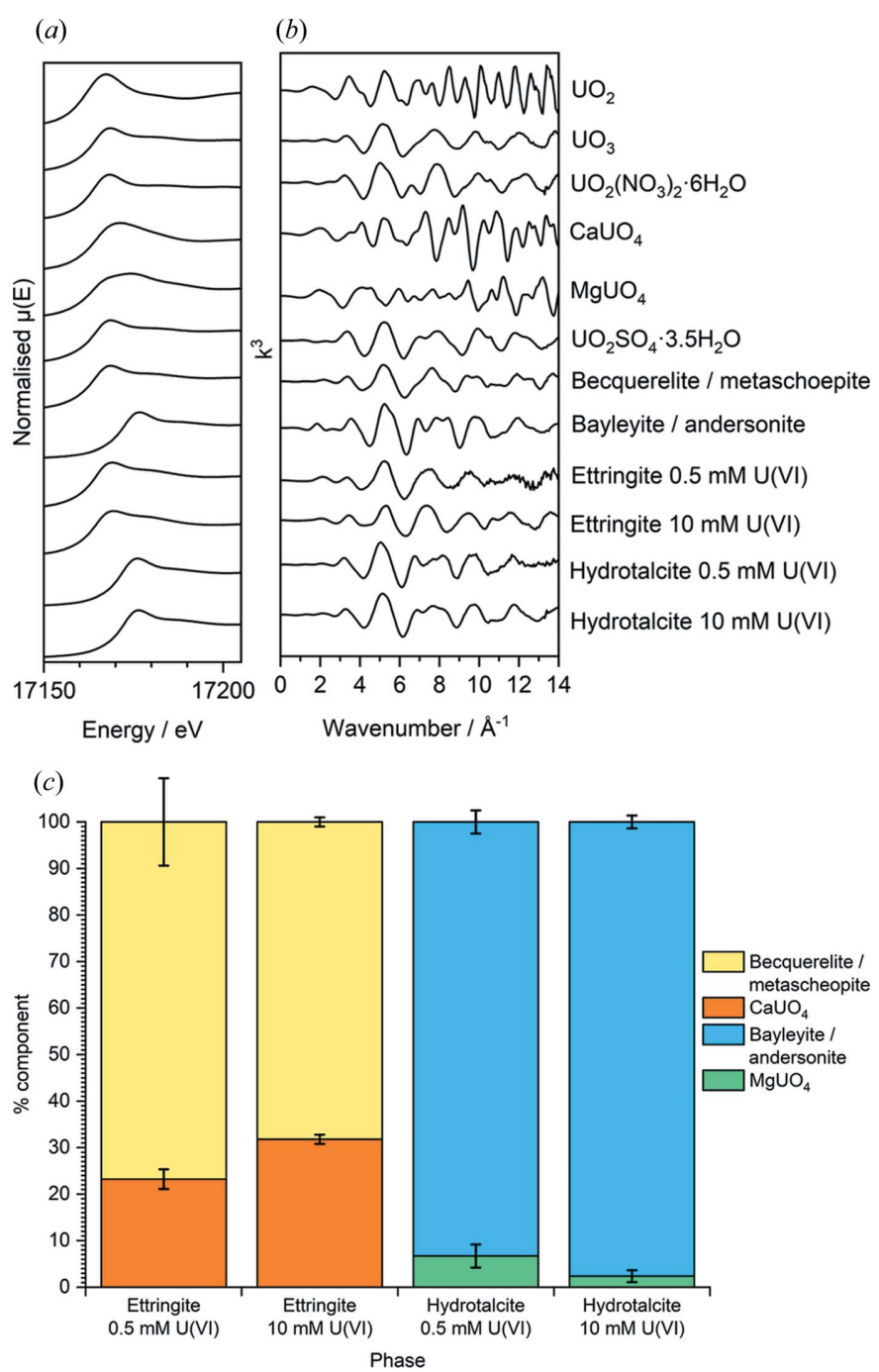

Figure 5

$\mathrm{U} L_{\mathrm{III}}$-edge energy spectra of all $\mathrm{U}^{\mathrm{VI}}$-contacted phases and mineral standards, showing $(a)$ the XANES region (normalized and offset for clarity); (b) the corresponding $k^{3}$-weighted EXAFS spectra (offset for clarity); and (c) a bar graph highlighting the percentage component of signals contributing to the linear combination fit of each system (graphical fits are given in the supporting information).

is indicative of the formation of a uranyl carbonate phase, which may be bonded to $\mathrm{Mg}$, in addition to the co-formation of a magnesium uranate type phase.

The $k^{3}$-weighted spectra and radial distribution profiles of the $\mathrm{U}^{\mathrm{VI}}$-contacted ettringite and hydrotalcite minerals, 
and subsequent EXAFS model fits for each, are shown in Fig. 6, with the fit parameters given in Table 5. Additionally, fit parameters for the mixed bayleyite/andersonite and mixed becquerelite/metaschoepite mineral phases are given.

For $\mathrm{U}^{\mathrm{VI}}$-contacted ettringite systems, the Fourier transform window was set between $k=\sim 3$ and $k=\sim 13 \AA^{-1}$. A combination of FEFF pathways was generated using the CIF files for metaschoepite $\left[\left(\left(\mathrm{UO}_{2}\right)_{4} \mathrm{O}(\mathrm{OH})_{6}\right)\left(\mathrm{H}_{2} \mathrm{O}\right)_{5}\right.$; ICSD No. $156714]$ and becquerelite $\left[\mathrm{Ca}\left(\left(\mathrm{UO}_{2}\right)_{6} \mathrm{O}_{4}(\mathrm{OH})_{6}\right)\left(\mathrm{H}_{2} \mathrm{O}\right)_{8}\right.$; ICSD No. 94620] (Burns \& Li, 2002; Klingensmith et al., 2007). For ettringite contacted with $0.5 \mathrm{~m} M \mathrm{U}^{\mathrm{VI}}$, the $\mathrm{O}_{\mathrm{ax}}$ distance was refined at $1.827 \pm 0.012 \AA$ with $N_{\mathrm{O} 1}=2.9 \pm 0.3$. A split equatorial shell was evident by fitting subsequent $\mathrm{O}_{\text {eq }}$ pathways refined at distances of $2.23 \pm 0.02,2.34 \pm 0.02,2.45 \pm$ 0.03 and $2.90 \pm 0.04 \AA$ with $N_{\mathrm{O} 2}=1, N_{\mathrm{O} 3}=2, N_{\mathrm{O} 4}=1$ and $N_{\mathrm{O} 5}=1$, respectively. A Ca scatterer was also fitted at $3.62 \pm$ $0.07 \AA$ with $N_{\mathrm{Ca} 1}=1$, by refining the pathway generated for the $\mathrm{U}-\mathrm{Ca}$ distance in becquerelite. A subsequent $\mathrm{U}$ distance was also fitted at $3.80 \pm 0.06 \AA$ with $N_{\mathrm{U} 1}=1$. It should be noted that the data for this phase were not well resolved after $\sim 10 \mathrm{~A}^{-1}$ in $k$, as demonstrated in Fig. 6(a).

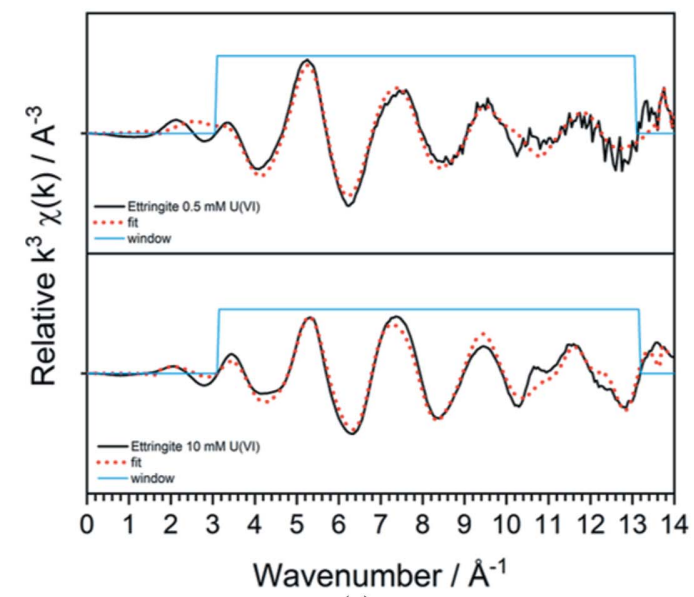

(a)

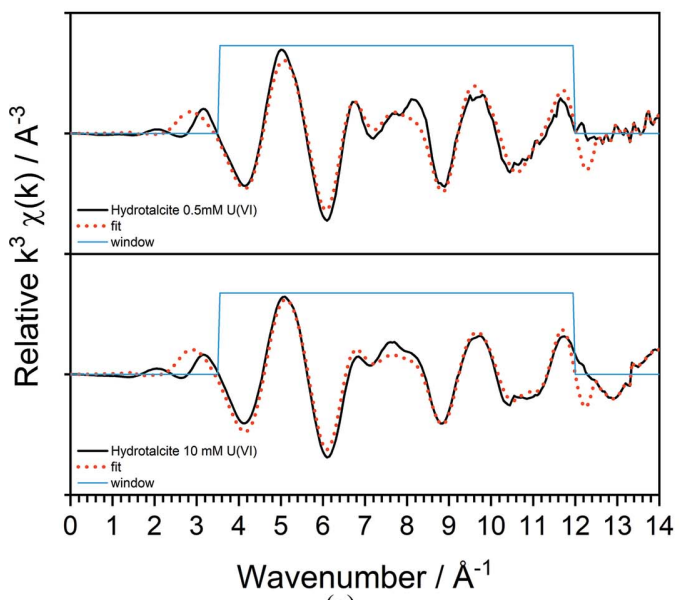

(c)
When the model used for the $0.5 \mathrm{~m} M \mathrm{U}^{\mathrm{VI}}$-ettringite data was applied to the $10 \mathrm{~m} M \mathrm{U}^{\mathrm{VI}}$-ettringite EXAFS data, it yielded a poor fit. Rather, a different model was devised that contained no U-Ca pathway. Instead, a U-C pathway was fitted, generated using the CIF file for andersonite $\left[\mathrm{Na}_{2} \mathrm{Ca}\left(\mathrm{UO}_{2}\left(\mathrm{CO}_{3}\right)_{3}\right) \cdot x\left(\mathrm{H}_{2} \mathrm{O}\right)\right.$; ICSD No. 15533] (Coda et al., 1981). This is suggestive of carbonation of the phase, likely from some unavoidable $\mathrm{CO}_{2}$ ingress during storage or measurement, leading to coordination of $\mathrm{U}$ to $\mathrm{C}$. The first $\mathrm{O}_{\mathrm{ax}}$ distance was refined at $1.837 \pm 0.008 \AA$ with $N_{\mathrm{O} 1}=1.7 \pm 0.2$. A split equatorial shell was also evident by fitting subsequent $\mathrm{O}_{\text {eq }}$ pathways refined at distances of $2.24 \pm 0.01,2.38 \pm 0.02,2.53 \pm$ $0.03 \AA$ with $N_{\mathrm{O} 2}=2, N_{\mathrm{O} 3}=2, N_{\mathrm{O} 4}=1$, respectively; however, these fitted distances were closer than with the $0.5 \mathrm{~m} M$ system. The C distance was refined at $2.91 \pm 0.05 \AA$ with $N_{\mathrm{C} 1}=1$, with two subsequent $\mathrm{U}$ scatterers also fitted at distances of $3.74 \pm$ 0.03 and $3.90 \pm 0.03 \AA$, both with $N_{\mathrm{U} 1,2}=1$. It should be noted that the MS pathways considered for $\mathrm{U}-\mathrm{O}_{\mathrm{ax}}-\mathrm{O}_{\mathrm{ax}}$ or $\mathrm{U}-\mathrm{O}_{\mathrm{ax}}-$ $\mathrm{O}_{\text {eq }}$ were not included in the fit for either of the $\mathrm{U}^{\mathrm{VI}}$-contacted ettringite minerals, due to the expected low-symmetry geometry of $\mathrm{U}^{\mathrm{VI}}$ in the phase formed, as discussed further in Section 4.1 .

Figure 6

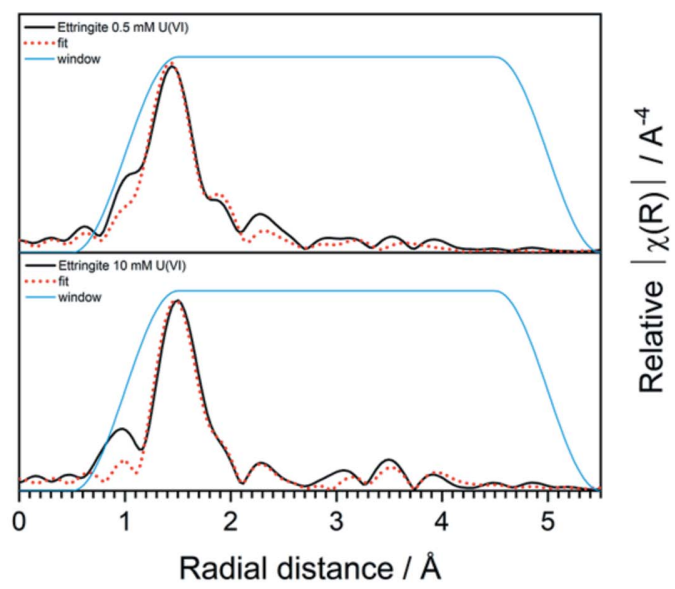

(b)

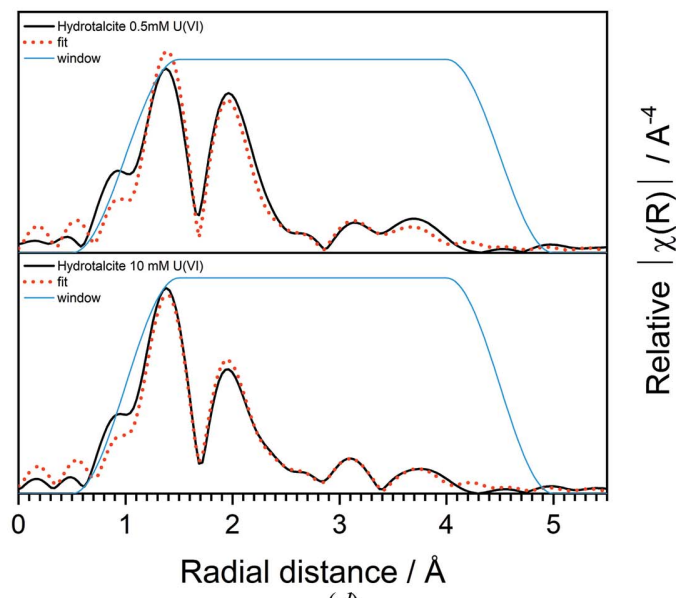

(d)

Local coordination analysis of $\mathrm{U}^{\mathrm{VI}}$ in contact with cement minerals. (a) $k^{3}$-weighted spectra and model fit (dashed red lines) for ettringite; $(b)$ corresponding Fourier-transformed radial plots; $(c) k^{3}$-weighted spectra and model fits (dashed red lines) for hydrotalcite; $(d)$ corresponding Fouriertransformed radial plots and fits. 
Table 5

EXAFS model parameters for $\mathrm{U}^{\mathrm{VI}}$-contacted ettringite and hydrotalcite minerals and mixed becquerelite/metaschoepite and bayleyite/andersonite mineral phases.

Numbers with no errors have been fixed in the model. $R=$ effective interatomic distance, $N=$ coordination number, $\sigma^{2}=$ Debye-Waller factor.

\begin{tabular}{|c|c|c|c|c|c|c|c|}
\hline Mineral & {$\left[\mathrm{U}^{\mathrm{VI}}\right](\mathrm{m} M)$} & $R$ factor & $\Delta E(\mathrm{eV})$ & Scatterer & $R(\AA)$ & $N$ & $\sigma^{2}$ \\
\hline \multirow[t]{7}{*}{ Ettringite } & \multirow[t]{3}{*}{0.5} & \multirow[t]{3}{*}{0.020} & \multirow[t]{3}{*}{$10(2)$} & $\mathrm{O}_{\mathrm{ax}}$ & $1.827(12)$ & $2.9(3)$ & $0.005(1)$ \\
\hline & & & & $\mathrm{O}_{\mathrm{eq}}$ & $2.23(2), 2.34(2), 2.48(4), 2.90(4)$ & $1,2,1,1$ & $0.005(1)$ \\
\hline & & & & $\mathrm{Ca}$ & $3.64(8)$ & 1 & $0.015(11)$ \\
\hline & \multirow[t]{4}{*}{10} & \multirow[t]{4}{*}{0.022} & \multirow[t]{4}{*}{$11(2)$} & $\mathrm{O}_{\mathrm{ax}}$ & $1.837(8)$ & $1.7(2)$ & $0.001(1)$ \\
\hline & & & & $\mathrm{O}_{\mathrm{eq}}$ & $2.24(1), 2.38(2), 2.53(3)$ & $2,2,1$ & $0.001(1)$ \\
\hline & & & & $\mathrm{C}$ & $2.91(5)$ & 1 & $0.004(6)$ \\
\hline & & & & $\mathrm{U}$ & $3.74(3)$ & 1 & $0.002(3)$ \\
\hline & & & \multirow{4}{*}{$8(1)$} & $\mathrm{O}_{\mathrm{eq}}$ & $2.44(1)$ & 4 & $0.0034(8)$ \\
\hline & & & & $\mathrm{C}$ & $2.93(2)$ & 3 & $0.001(2)$ \\
\hline & & & & $\mathrm{U}$ & $3.39(3)$ & 2 & $0.004(2)$ \\
\hline & & & & $\mathrm{Mg}$ & $3.83(2)$ & 4 & $0.001(2)$ \\
\hline & \multirow[t]{3}{*}{10} & \multirow[t]{3}{*}{0.009} & \multirow[t]{3}{*}{$9(1)$} & $\mathrm{O}_{\mathrm{ax}}^{\dagger}$ & $1.815(9)$ & $2.8(2)$ & $0.0048(8)$ \\
\hline & & & & $\mathrm{O}_{\mathrm{eq}}$ & $2.43(1)$ & 4 & $0.0048(8)$ \\
\hline & & & & $\mathrm{C}$ & $2.92(2)$ & 3 & $0.002(2)$ \\
\hline \multirow{2}{*}{ ecquerelite/metaschoepite $\ddagger$} & \multirow{2}{*}{-} & \multirow{2}{*}{0.017} & \multirow{2}{*}{$9(2)$} & $U^{4}$ & $3.89(2)$ & 1 & $0.004(1)$ \\
\hline & & & & $\mathrm{U}$ & $4.60(3)$ & 1 & $0.004(1)$ \\
\hline \multirow[t]{6}{*}{ Bayleyite/andersonite $\$$} & \multirow[t]{6}{*}{-} & \multirow[t]{6}{*}{0.023} & \multirow[t]{6}{*}{$9(2)$} & $\mathrm{O}_{\mathrm{ax}}^{\dagger}$ & $1.796(8)$ & $2.5(3)$ & $0.0031(7)$ \\
\hline & & & & $\mathrm{O}_{\mathrm{eq}}$ & $2.43(1)$ & 4 & $0.0031(7)$ \\
\hline & & & & $\mathrm{C}$ & $2.91(2)$ & 3 & $0.01(2)$ \\
\hline & & & & $\mathrm{Na}$ & $3.71(5)$ & 1 & 0.0001 \\
\hline & & & & $\mathrm{Ca}$ & $3.98(2)$ & 2 & $0.001(2)$ \\
\hline & & & & $\mathrm{O}$ & $4.31(9)$ & 2 & $0.0031(7)$ \\
\hline
\end{tabular}

$\dagger$ MS pathways also fitted at approximately twice the $\mathrm{O}_{\mathrm{ax}}$ distance. $\$$ Graphical fits are shown in the supporting information.

For $\mathrm{U}^{\mathrm{VI}}$-contacted hydrotalcite systems, the Fourier transform window was set between $k=\sim 3.5$ and $k=\sim 12 \AA^{-1}$. A combination of $F E F F$ pathways was generated using the CIF files for bayleyite $\left[\mathrm{Mg}_{2}\left(\mathrm{UO}_{2}\left(\mathrm{CO}_{3}\right)_{3}\right) \cdot 18 \mathrm{H}_{2} \mathrm{O} ; \mathrm{ICSD}\right.$ No. 32101] and magnesium orthouranate $\left[\mathrm{Mg}\left(\mathrm{UO}_{2}\right)_{2}\right.$; ICSD No. 24725] (Zachariasen, 1954; Mayer \& Mereiter, 1986). For hydrotalcite contacted with $0.5 \mathrm{~m} M \mathrm{U}^{\mathrm{VI}}$, the $\mathrm{O}_{\mathrm{ax}}$ distance was refined at $1.814 \pm 0.009 \AA$ with $N_{\mathrm{O} 1}=2.5 \pm 0.2$. The subsequent $\mathrm{O}_{\text {eq }}$ pathway was refined at $2.44 \pm 0.01 \AA$ with $N_{\mathrm{O} 2}=4$. A C scatterer was fitted at a distance of $2.93 \pm 0.02 \AA$ with $N_{\mathrm{C} 1}=3$, by refining the pathway generated for the U-C distance in bayleyite. A U scatterer was also fitted at $3.39 \pm 0.03 \AA$ with $N_{\mathrm{U} 1}=2$, by refining the pathway generated for the U-U distance in magnesium orthouranate. A subsequent $\mathrm{Mg}$ distance was also fitted at $3.83 \pm 0.02 \AA$ with $N_{\mathrm{Mg} 1}=4$.

It was possible to fit the $10 \mathrm{~m} M \mathrm{U}^{\mathrm{VI}}$-contacted hydrotalcite data with the same model, and the distances refined were the same within error. The value of $N_{\mathrm{O} 1}$ refined for $\mathrm{O}_{\mathrm{ax}}$ was slightly increased at $2.8 \pm 0.2$. It should be noted that an $\mathrm{Al}$ scatterer at the same distance in place of $\mathrm{Mg}$ also yielded a similar fit and $R$ factor; however the results from ${ }^{27} \mathrm{Al}$ MASNMR analyses justify the fitting of $\mathrm{Mg}$ in this case (see Section 3.4).

The $\mathrm{U}-\mathrm{O}_{\mathrm{ax}}-\mathrm{O}_{\mathrm{ax}}$ MS pathway was also fitted at approximately twice the distance of $R$ for the SS $\mathrm{U}-\mathrm{O}_{\mathrm{ax}}$ pathway in both the $\mathrm{U}^{\mathrm{VI}}$-contacted hydrotalcite phases. The contribution to the fit was minor in both cases, and contributions at $R>3 \AA$ were largely dominated by $\mathrm{Mg}$ and $\mathrm{U}$ single scatterers rather than the MS pathway.

\subsection{Influence of $U^{\mathrm{VI}}$ on the chemical environment of $\mathrm{Al}$}

The normalized ${ }^{27} \mathrm{Al}$ MAS-NMR spectra of pure-phase and $\mathrm{U}^{\mathrm{VI}}$-contacted ettringite phases are shown in Fig. 7(a). The main peak exhibited an observed chemical shift $\left(\delta_{\text {obs }}\right)$ at $\delta_{\text {obs }}=$ $15 \mathrm{ppm}$, which arises from the two octahedrally coordinated $\mathrm{Al}$ sites in ettringite that cannot be further resolved at the magnetic field used in this study (9.4 T) (Skibsted et al., 2017). These sites are denoted as 'Ett-Al'. There is an additional small, broad peak at $\delta_{\text {obs }}=\sim 10 \mathrm{ppm}$ present in the pure-phase ettringite phase, appearing as a shoulder of the main ettringite peak, which is attributed to octahedrally coordinated $\mathrm{Al}$ in calcium aluminate monosulfate phases $\left[\mathrm{AFm}, \mathrm{Ca}_{4}\left(\mathrm{Al}_{2} \mathrm{O}_{6}\right)\right.$ $\left.\left(\mathrm{SO}_{4}\right) \cdot 12 \mathrm{H}_{2} \mathrm{O}\right]$. This arises from minor impurities of this phase, remnant from the synthesis process and not detectable by XRD. This site is denoted as 'AFm-Al' (Skibsted et al., 1993).

The peak arising from octahedral $\mathrm{Al}$ in ettringite was maintained after contact of the phase with $\mathrm{U}^{\mathrm{VI}}$ at both concentrations [Fig. 7(a)]. This is consistent with the retention of diffraction peaks for ettringite in the corresponding XRD patterns. However, the shoulder for the octahedral Al sites in AFm was only observed in the pristine sample and the phase 
contacted with $10 \mathrm{~m} M \mathrm{U}^{\mathrm{VI}}$, albeit at a slightly lower intensity than in the pristine mineral phase [Fig. 7(b)]. This behaviour could be attributed to two possible scenarios, given that $\mathrm{Al}$ release into solution was higher for the $0.5 \mathrm{~m} M \mathrm{U}^{\mathrm{VI}}$ sample

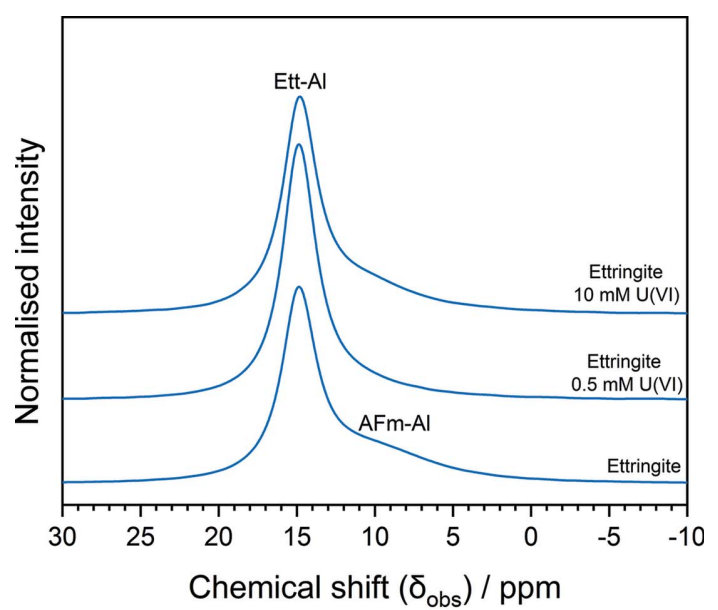

(a)

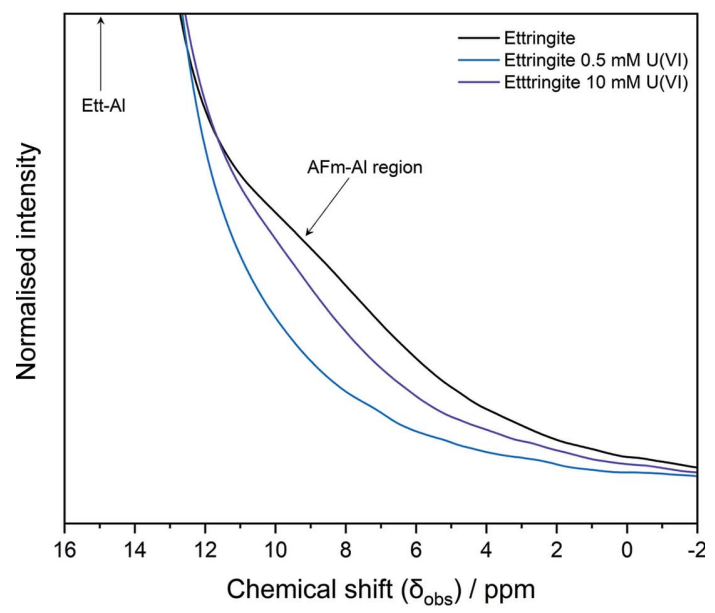

(b)

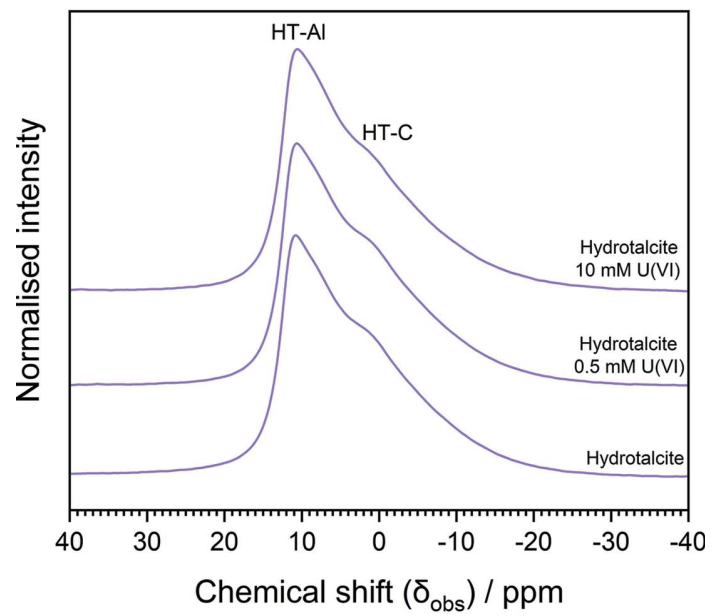

(c)

Figure 7

${ }^{27} \mathrm{Al}$ MAS-NMR $\left(B_{0}=11.7 \mathrm{~T}, v_{R}=12.5 \mathrm{kHz}\right)$ spectra of $(a)$ pristine ettringite and ettringite contacted with $0.5 \mathrm{~m} M$ and $10 \mathrm{~m} M \mathrm{U}^{\mathrm{VI}} ;(b)$ the same data as (a) but highlighting the 'AFm-Al' region of the spectra; and (c) pristine hydrotalcite and hydrotalcite contacted with $0.5 \mathrm{mM}$ and $10 \mathrm{~m} M \mathrm{U}^{\mathrm{VI}}$. when compared with the $10 \mathrm{~m} M \mathrm{U}^{\mathrm{VI}}$ sample: (i) increased dissolution of the impurity $\mathrm{AFm}$ phase at $0.5 \mathrm{~m} M \mathrm{U}^{\mathrm{VI}}$ and/or

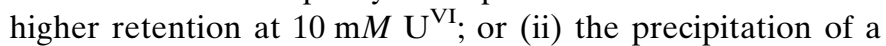
poorly crystalline or low-yield U-substituted AFm phase in the $10 \mathrm{~m} M \mathrm{U}^{\mathrm{VI}}$-contacted sample, given that $\mathrm{AFm}$ is a $\mathrm{LDH}$ that can display ion-exchange capabilities (Aimoz et al., 2012).

The normalized ${ }^{27} \mathrm{Al}$ MAS-NMR spectra of pristine and $\mathrm{U}^{\mathrm{VI}}$-contacted hydrotalcite phases are shown in Fig. 7(c). The spectra displayed a peak at $\delta_{\text {obs }}=11 \mathrm{ppm}$, which is attributed to the single octahedrally coordinated $\mathrm{Al}$ environment in hydrotalcite that is surrounded by octahedrally coordinated Mg atoms (Walkley \& Provis, 2019; Sideris et al., 2012). This peak is denoted as 'HT-Al'. There was also a shoulder observed at $\delta=1-3 \mathrm{ppm}$ in all spectra, which arises due to shielding of some of the $\mathrm{Al}$ atoms due to the presence of $\mathrm{CO}_{3}{ }^{2-}$ interlayer anions in hydrotalcite (denoted as 'HT-C') (Walkley \& Provis, 2019; Sideris et al., 2012). The observation of these peaks at all concentrations of $\mathrm{U}^{\mathrm{VI}}$ contact is consistent with the retention of diffuse diffraction peaks for hydrotalcite in the corresponding XRD patterns. There was no notable change observed in the spectra as a result of $\mathrm{U}^{\mathrm{VI}}$ contact at both concentrations, which suggests that no significant solidphase structural interaction of $\mathrm{U}^{\mathrm{VI}}$ with $\mathrm{Al}$ within the hydrotalcite phase occurred.

\section{Discussion}

4.1. U $U^{\mathrm{VI}}$-ettringite systems

In the ettringite system, the XRD peaks for ettringite were maintained upon contact with both concentrations of $\mathrm{U}^{\mathrm{VI}}$. However, identification of an amorphous region in the XRD pattern could be the result of a poorly crystalline $\mathrm{Al}-$ or Caand $\mathrm{U}^{\mathrm{VI}}$-bearing phase. Geochemical modelling estimations and previous literature allude to the formation of a calcium uranate type phase as the most highly saturated $\mathrm{U}^{\mathrm{VI}}$-bearing phase, due to the abundance of $\mathrm{Ca}$ in the system.

The results from the XANES region linear combination fitting analyses indicate that the XANES region was largely dominated by a signal similar to that of the mixed becquerelite/metaschoepite mineral phase at both concentrations of $\mathrm{U}^{\mathrm{VI}}$. This indicates that the uranyl moiety $[\mathrm{O}=\mathrm{U}=\mathrm{O}]^{2+}$ was maintained, and with reference to the EXAFS model fits this is likely to be in a pentagonal bipyramidal coordination given that a total of $N_{\text {Oeq }}=5$ were fitted for samples of ettringite exposed to $0.5 \mathrm{~m} M$ and $10 \mathrm{~m} M \mathrm{U}^{\mathrm{VI}}$. This is also consistent with the $\mathrm{U}^{\mathrm{VI}}$ geometry found in becquerelite (Colmenero et al., 2018) (see also the EXAFS model fit for mixed becquerelite/metaschoepite in Table 5). In uranyl compounds that display this low-symmetry coordination geometry, it has been shown that contributions from MS pathways are very minor and do not contribute significantly to spectral features (Thompson et al., 1997). This was evident when performing the fits and accounts for the exclusion of the MS pathways for the $\mathrm{U}^{\mathrm{VI}}$-contacted ettringite phases (and becquerelite/metaschoepite mineral). Whilst signal contribution from a calcium uranate type environment was also indicated by XANES 
linear combination fitting, it is likely that this would form in this system as a hydrous analogue $\left[\right.$ e.g. $\left.\mathrm{CaU}_{2} \mathrm{O}_{7} \cdot x \mathrm{H}_{2} \mathrm{O}_{\text {(cr) }}\right]$ (Çevirim-Papaioannou et al., 2018). Calcium uranate phases have previously been found to form in cementitious systems (Sutton et al., 2003; Felipe-Sotelo et al., 2017).

Although the EXAFS model fits of the two $\mathrm{U}^{\mathrm{VI}}$-contacted ettringite systems varied most notably by inclusion/exclusion of $\mathrm{Ca} / \mathrm{C}$ scattering atoms, this is thought to be a result of unavoidable carbonation of the $10 \mathrm{~m} M \mathrm{U}^{\mathrm{VI}}$-contacted ettringite phase during preparation or analysis. In this case, the fitting of a $\mathrm{C}$ scatterer suggests the formation of a uranyl carbonate type phase, whereby $\mathrm{U}^{\mathrm{VI}}$ could be coordinated to a carbonate ligand. Such a phase would thus display a XANES signal that is not easily distinguishable from that of a becquerelite-type phase or the $0.5 \mathrm{~m} M$ phase. However, the EXAFS model interpretation must be treated with some caution, as $\mathrm{C}$ and $\mathrm{Ca}$ are relatively low- $Z$ atoms and may not display a large contribution to the EXAFS signal, especially in such disordered and multi-phase systems. The fitting of $U$ scatterers in both cases was a strong indication that a secondary $\mathrm{U}^{\mathrm{VI}}$ precipitate was formed.

From the ${ }^{27} \mathrm{Al}$ NMR data, a significant change in the main peak corresponding to the octahedrally coordinated $\mathrm{Al}$ sites in ettringite was not observed as a result of $\mathrm{U}^{\mathrm{VI}}$ contact. This suggests that there was no incorporation of $\mathrm{U}^{\mathrm{VI}}$, for example, into the columnar channels of the ettringite structure, even at the 'borderline trace' (i.e. sorption-controlled) concentration of $\mathrm{U}^{\mathrm{VI}}(0.5 \mathrm{~m} M)$. It is thought that a close proximity of $\mathrm{U}^{\mathrm{VI}}$ to $\mathrm{Al}$ hydroxide polyhedra in this way would result in a downward shift in $\delta_{\text {obs, }}$, as a result of increased shielding of Al nuclei by $\mathrm{U}$. Considering these observations, it seems plausible that at both concentrations of $\mathrm{U}^{\mathrm{VI}}$ a poorly crystalline surface or secondary precipitate containing $\mathrm{Ca}$ would be partly responsible for the sequestration of $\mathrm{U}^{\mathrm{VI}}$ in an ettringite-only system.

The presence of an AFm- $\mathrm{SO}_{4}\left(\mathrm{Ca}_{4}\left(\mathrm{Al}_{2} \mathrm{O}_{6}\right)\left(\mathrm{SO}_{4}\right) \cdot x \mathrm{H}_{2} \mathrm{O}\right)$ impurity in the ettringite phase was indicated by the shoulder on the main ettringite peak, at $\sim 10 \mathrm{ppm}$ by ${ }^{27} \mathrm{Al}$ MAS-NMR. This peak was shown to diminish for the sample contacted with $0.5 \mathrm{~m} M \mathrm{U}^{\mathrm{VI}}$, but it was evident for the sample contacted with $10 \mathrm{mM} \mathrm{U}^{\mathrm{VI}}$. This behaviour coincides with the relative leaching of $\mathrm{Al}$ from ettringite upon contact with the low-pH uranyl nitrate bearing solution [Fig. 2(b)], i.e. the $0.5 \mathrm{~m} M \mathrm{U}^{\mathrm{VI}}$ contacted sample released more $\mathrm{Al}$ into solution than the $10 \mathrm{~m} M \mathrm{U}^{\mathrm{VI}}$-contacted sample; therefore, in the former, the $\mathrm{AFm}-\mathrm{SO}_{4}$ phase was not retained, while in the latter it was. However, since the relative leaching of $\mathrm{Ca}$ and $\mathrm{S}$ was higher in the $10 \mathrm{~m} M \mathrm{U}^{\mathrm{VI}}$ solution than in the $0.5 \mathrm{~m} M \mathrm{U}^{\mathrm{VI}}$ solution, due to the lower $\mathrm{pH}$ of the former ( $\mathrm{pH} \sim 2.8$ and $\sim 3.6$, for $10 \mathrm{~m} M$ $\mathrm{U}^{\mathrm{VI}}$ and $0.5 \mathrm{~m} M \mathrm{U}^{\mathrm{VI}}$, respectively), if one assumes that in the $10 \mathrm{~m} M \mathrm{U}^{\mathrm{VI}}$ solution ettringite was leached more than in the $0.5 \mathrm{mM} \mathrm{U}^{\mathrm{VI}}$ solution, then the discrepancy in $\mathrm{Al}$ leaching may be attributed to the formation of a secondary $\mathrm{Al}$ phase that incorporates $\mathrm{U}^{\mathrm{VI}}$, potentially $\mathrm{AFm}-\mathrm{U}^{\mathrm{VI}}$.

While it has been shown that $\mathrm{AFt}_{-} \mathrm{SO}_{4}$ (i.e. ettringite) phases have capacity for the uptake of anionic species such as pertechnetate $\left(\mathrm{TcO}_{4}{ }^{-}\right)$(Saslow et al., 2020), evidence for the same behaviour in $\mathrm{AFm}-\mathrm{SO}_{4}$ phases is more limited. One example is that of iodate $\left(\mathrm{I}^{-}\right)$, which has been shown to incorporate into the interlayer of $\mathrm{AFm}-\mathrm{SO}_{4}$ to form an $\mathrm{AFm}$ phase with a mixed sulfate and iodate interlayer (Aimoz et al., 2012). The results from geochemical modelling performed in the present study indicated the presence of uranyl hydroxide/ sulfate anions in solution at the $\mathrm{pH}$ values of the ettringite solutions ( $\mathrm{pH} \sim 10)$, including: $\left(\mathrm{UO}_{2}\right)_{3}(\mathrm{OH})_{7}{ }^{-}, \mathrm{UO}_{2}(\mathrm{OH})_{3}{ }^{-}$, $\mathrm{UO}_{2}(\mathrm{OH})_{4}{ }^{2-}$ and $\mathrm{UO}_{2}\left(\mathrm{SO}_{4}\right)_{2}{ }^{2-}$. The precipitation of an AFm$\mathrm{U}^{\mathrm{VI}}$ phase is therefore plausible, with the higher concentration of $\mathrm{U}^{\mathrm{VI}}$ in the $10 \mathrm{~m} M$ solution, and thus higher $\mathrm{U}^{\mathrm{VI}}$ uptake is required for formation and/or detection of this phase by NMR.

From the species identified by geochemical modelling, the $\mathrm{UO}_{2}(\mathrm{OH})_{4}{ }^{2-}$ and $\mathrm{UO}_{2}\left(\mathrm{SO}_{4}\right)_{2}{ }^{2-}$ anions are the most likely candidates that could directly exchange into an $\mathrm{AFm}-\mathrm{SO}_{4}$ interlayer, potentially forming ' $\mathrm{Ca}_{4}\left(\mathrm{Al}_{2} \mathrm{O}_{6}\right)$ $\left(\mathrm{UO}_{2}(\mathrm{OH})_{4}\right) \cdot x \mathrm{H}_{2} \mathrm{O}$ '- and ' $\mathrm{Ca}_{4}\left(\mathrm{Al}_{2} \mathrm{O}_{6}\right)\left(\mathrm{UO}_{2}\left(\mathrm{SO}_{4}\right)_{2}\right) \cdot x \mathrm{H}_{2} \mathrm{O}$ 'type phases, respectively, taking into account the charge balance. However, given that the ionic radius of a sulfate anion $\left(\mathrm{SO}_{4}{ }^{2-}\right)$ is $2.42 \AA$ (Marcus, 1988), the aforementioned uranyl hydroxide or uranyl sulfate anion combinations would encompass a much larger ionic radius $\left[\right.$ e.g. $\mathrm{OH}^{-}=1.1 \AA$ (Marcus, 2012); $\mathrm{UO}_{2}{ }^{2+} \simeq 0.95 \AA$ (Dean et al., 2008)]. An anion-exchange process may therefore be size limited and identification of such a phase is speculative without further evidence from analysis of a solely $\mathrm{U}^{\mathrm{VI}}$-exchanged $\mathrm{AFm}-\mathrm{SO}_{4}$ phase.

\section{2. $U^{\mathrm{VI}}$-hydrotalcite systems}

For the $\mathrm{U}^{\mathrm{VI}}$-contacted hydrotalcite systems, no significant change in the XRD pattern was observed when compared with the pristine hydrotalcite. However, approximately $30 \%$ of $\left[\mathrm{U}^{\mathrm{VI}}\right]_{t=0}$ was removed from solution at both concentrations of $\mathrm{U}^{\mathrm{VI}}$, indicating that $\mathrm{U}^{\mathrm{VI}}$ was sequestered by the solid phase to some extent.

The results from the XANES linear combination fitting and EXAFS model fitting of the $\mathrm{U}^{\mathrm{VI}}$-contacted hydrotalcite systems indicated that the coordination of $\mathrm{U}^{\mathrm{VI}}$ was largely unchanged as a function of $\mathrm{U}^{\mathrm{VI}}$ concentration. A large contribution to the XANES signal linear combination fit in both cases was attributed to the mixed bayleyite/andersonite mineral phase. This indicates that the uranyl moiety $[\mathrm{O}=\mathrm{U}=\mathrm{O}]^{2+}$ was maintained. With reference to the EXAFS model fit, the value of $N_{\mathrm{O}_{2}}=4$ for $\mathrm{O}_{\mathrm{eq}}$ agrees with the value of $N_{\mathrm{O} 2}$ for that of the uranyl carbonate mixed bayleyite/andersonite mineral phase. These minerals both display a hexagonal bipyramidal $\mathrm{U}^{\mathrm{VI}}$ geometry (Mayer \& Mereiter, 1986; Coda et al., 1981). A small signal contribution from magnesium uranate in both cases was also indicated in the XANES region; as with calcium uranate, it is likely that this phase would be hydrous in nature $\left[\right.$ e.g. $\mathrm{MgU}_{2} \mathrm{O}_{7} \cdot x \mathrm{H}_{2} \mathrm{O}_{(\text {cr) }}$ ] (Yalçıntaş et al., 2019).

The $\mathrm{O}_{\mathrm{ax}}, \mathrm{O}_{\mathrm{eq}}$ and $\mathrm{C}$ distances obtained in the EXAFS model fits for the $\mathrm{U}^{\mathrm{VI}}$-contacted hydrotalcite systems are also fairly typical of a uranyl carbonate phase. The distances are summarized in Table 6, and compared with the values 
Table 6

Summary of the $\mathrm{U}-X$ distances obtained by EXAFS model fitting of $0.5 \mathrm{~m} M$ and $10 \mathrm{~m} M \mathrm{U}^{\mathrm{VI}}$-contacted hydrotalcite, bayleyite/andersonite and $\mathrm{U}^{\mathrm{VI}}$ contacted magnesium and/or carbonate mineral phases.

Note that errors were not quoted by van Veelen $e t$ al. (2018).

\begin{tabular}{|c|c|c|c|c|c|c|}
\hline Phase & $\mathrm{O}_{\mathrm{ax}}(\AA)$ & $\mathrm{O}_{\text {eq }}(\AA)$ & $\mathrm{C}(\AA)$ & $\operatorname{Mg}(\AA)$ & $\mathrm{U}(\AA)$ & Reference \\
\hline Hydrotalcite $0.5 \mathrm{~m} M \mathrm{U}^{\mathrm{VI}}$ & $1.82(1)$ & $2.44(1)$ & $2.91(1)$ & $3.83(3)$ & $3.39(3)$ & This work \\
\hline Hydrotalcite $10 \mathrm{~m} M \mathrm{U}^{\mathrm{VI}}$ & $1.819(8)$ & $2.44(1)$ & $2.93(1)$ & $3.85(2)$ & $3.41(2)$ & This work \\
\hline Bayleyite/andersonite & $1.796(9)$ & $2.43(12)$ & $2.91(2)$ & - & - & This work \\
\hline Brucite $+\mathrm{U}^{\mathrm{VI}}$ & 1.80 & $2.38,2.48$ & $2.90 \dagger$ & 3.60 & 3.88 & van Veelen et al. (2018) \\
\hline Hydromagnesite $+\mathrm{U}^{\mathrm{VI}}$ & 1.81 & 2.43 & 2.90 & 3.62 & 3.90 & van Veelen et al. (2018) \\
\hline Nesquehonite $+\mathrm{U}^{\mathrm{VI}}$ & 1.81 & $2.40,2.50$ & 2.90 & 3.59 & 3.89 & van Veelen et al. (2018) \\
\hline
\end{tabular}

$\dagger \mathrm{C}$ was thought to be present due to the formation of $\mathrm{UO}_{2}\left(\mathrm{CO}_{3}\right)_{3}{ }^{4-}$ in solution under the ambient experimental conditions adopted by van Veelen et al. (2018).

obtained for the mixed bayleyite/andersonite phase (EXAFS model fits given in Table 5) and for those reported by van Veelen et al. (2018) for brucite $\left(\mathrm{Mg}(\mathrm{OH})_{2}\right)$, hydromagnesite $\left(\mathrm{Mg}_{5}\left(\mathrm{CO}_{3}\right)_{4}(\mathrm{OH})_{2} \cdot 4 \mathrm{H}_{2} \mathrm{O}\right)$ and nesquehonite $\left(\mathrm{MgCO}_{3} \cdot 3 \mathrm{H}_{2} \mathrm{O}\right)$ minerals contacted with a $2 \mathrm{mM}$ uranyl nitrate solution at $\sim 34 \mathrm{~g} \mathrm{l}^{-1}$.

In the results obtained by van Veelen et al. (2018), $\mathrm{Mg}$ and U scatterers were fitted at distances of $\sim 3.6 \AA$ and $\sim 3.9 \AA$, respectively. This is in contrast to the result obtained here for hydrotalcite, where $\mathrm{Mg}$ and $\mathrm{U}$ were fitted conversely at $\sim 3.8$ and $\sim 3.4 \AA$, respectively. This could be a result of the $\mathrm{U}^{\mathrm{VI}}$ coordination having mixed magnesium uranate character in conjunction with the formation of a uranyl carbonate phase, whereby the scattering $\mathrm{U}$ atom is at a closer scattering distance in magnesium uranate phases, compared with its relative position in a uranyl carbonate phase only (Zachariasen, 1954).

The ${ }^{27} \mathrm{Al}$ MAS-NMR spectra for hydrotalcite are unchanged as a result of $\mathrm{U}^{\mathrm{VI}}$ addition to hydrotalcite which indicates that $\mathrm{Al}$ did not play a role in the uptake and coordination of $\mathrm{U}^{\mathrm{VI}}$, therefore supporting the concept of $\mathrm{Mg}$ as the scattering atom in the EXAFS model. This is consistent with the formation of a $\mathrm{U}^{\mathrm{VI}}, \mathrm{Mg}, \mathrm{C}$-containing surface precipitate or sorbed species, rather than anion-exchange into the hydrotalcite interlayer. This observation is also in agreement with the work of van Veelen et al. (2018), who proposed that $\mathrm{U}^{\mathrm{VI}}$ was sorbed to the surface of Mg-bearing minerals as an outersphere complex. The sequestration of $\mathrm{U}^{\mathrm{VI}}$ by carbonate in this case is highly conceivable given the presumed abundance of carbonate released into solution by the hydrotalcite phases, and the fact that carbonate has a high affinity for $\mathrm{U}^{\mathrm{VI}}$ complexation (Sutton et al., 2003).

\subsection{Implications for waste disposal}

For the ettringite systems, uptake of $\mathrm{U}^{\mathrm{VI}}$ directly by the ettringite phase was not apparent. Rather, the formation of a poorly crystalline hydrous $\mathrm{Ca}$-containing phase was more plausible. In addition to this, uptake by an AFm impurity contained within the system seemed a more likely mechanism for $\mathrm{U}^{\mathrm{VI}}$ structural uptake. Like ettringite, $\mathrm{AFm}-\mathrm{SO}_{4}$ phases are prominent LDH phases that are present in cement matrices, particularly for blast-furnace slag containing blends. Therefore, these should be further investigated to understand their capacity for uptake of $\mathrm{U}^{\mathrm{VI}}$. Further to this, the devel- opment of calcium sulfoaluminate (CSA) cements shows potential for applications in radioactive waste management, and such cements will encompass high levels of ettringite and AFm-SO ${ }_{4}$ phases (Zhou et al., 2006). Understanding the role that sulfate-containing minerals play in sequestration of highly mobile actinides is therefore pertinent to underpinning the effectiveness of cement blends used for radioactive waste encapsulation, both now and in the future.

The hydrotalcite phases also displayed uptake of $\mathrm{U}^{\mathrm{VI}}$ through formation of what was concluded to be a surfacesorbed uranyl magnesium carbonate phase, similar to the mineral phase bayleyite, but potentially with some mixed magnesium uranate character. $\mathrm{Mg}$ - and $\mathrm{Al}$-containing cement blends, where hydrotalcite forms during hydration, may therefore show good sequestration of aqueous $\mathrm{U}^{\mathrm{VI}}$ if it is immobilized by association to carbonate and $\mathrm{Mg}$. These findings could also be important if $\mathrm{Mg}(\mathrm{OH})_{2}$ sludge wastes are to be immobilized using a cement binder in the future; the high concentration of $\mathrm{Mg}$ associated with such sludges derived from the UK Magnox programme will likely lead to formation of significant deposits of hydrotalcite-type LDH minerals within the cement matrix (Walling et al., 2014), which will be able to effectively immobilize $\mathrm{U}^{\mathrm{VI}}$ also present in the waste itself.

\section{Conclusions}

Consideration of minor cement hydrate phases for the sequestration of $\mathrm{U}^{\mathrm{VI}}$ in cement matrices has not been widely reported. Here, for the first time we have probed the solidstate chemistry of ettringite and hydrotalcite minerals that have been subjected to aqueous solutions of $\mathrm{U}^{\mathrm{VI}}$ using XRD, $\mathrm{U} L_{\mathrm{III}}$-edge XAS and ${ }^{27} \mathrm{Al}$ MAS-NMR; these studies are relevant to understanding radioactive waste disposal of actinide-containing materials in cements.

Ettringite phases showed $>99 \%$ uptake of $\mathrm{U}^{\mathrm{VI}}$ from solution. Although direct incorporation of $\mathrm{U}^{\mathrm{VI}}$ into the ettringite structure was not observed in this case, the abundance of Ca in the ettringite systems was likely responsible for sequestering $\mathrm{U}^{\mathrm{VI}}$ within a Ca-bearing uranyl oxyhydroxide phase or as a hydrous calcium uranate type phase, as indicated by XAS results. This is in agreement with the previous studies that have determined $\mathrm{Ca}$ to be solubility limiting for $\mathrm{U}^{\mathrm{VI}}$ in high- 
Ca (i.e. cementitious) systems (Sutton et al., 2003; FelipeSotelo et al., 2017). ${ }^{27} \mathrm{Al}$ MAS-NMR results indicated that there was no change in the $\mathrm{Al}$ coordination environment in the ettringite structure; however, the presence of, or formation of, an $\mathrm{AFm}-\mathrm{SO}_{4}$ phase that may incorporate $\mathrm{U}^{\mathrm{VI}}$ was alluded to by changes in the 'AFm-Al' region of the NMR spectrum. Further investigation into the sorption and anion-exchange capacity of AFm phases for $\mathrm{U}^{\mathrm{VI}}$ (aq) is required.

Hydrotalcite phases displayed some limited $\mathrm{U}^{\mathrm{VI}}$ uptake $(\sim 30 \%)$ and XAS results indicated that this was attributed to the formation of a precipitated or sorbed uranyl carbonate phase. ${ }^{27} \mathrm{Al}$ MAS-NMR results showed that there was no observable change in the $\mathrm{Al}$ coordination environments in the hydrotalcite phases, leading to the conclusion that the uranyl carbonate phase was a Mg-containing uranyl carbonate phase. This highlights the importance of carbonate in LDH and/or cementitious systems for sequestering $\mathrm{U}^{\mathrm{VI}}$, a scenario that is corroborated by the strong tendency of carbonate to complex $\mathrm{U}^{\mathrm{VI}}$ and form uranyl carbonate species.

\section{Acknowledgements}

Stephen Parry and Giannantonio Cibin are gratefully acknowledged for their assistance with data collection at Diamond Light Source. Collection of ${ }^{27} \mathrm{Al}$ MAS-NMR data was performed at the Department of Chemistry, University of Sheffield by Sandra van Meurs and Craig Robertson.

\section{Funding information}

This research was performed in part at the HADES/MIDAS facility at the University of Sheffield established with financial support from the EPSRC and BEIS, under grant No. EP/ T011424/1. We acknowledge financial support from the Nuclear Decommissioning Authority and the DISTINCTIVE consortium under EPSRC grant No. EP/L01404/1. CLC would also like to thank the EPSRC for the award of an Early Career Research Fellowship under grant No. EP/N017374/1. Collection of $\mathrm{U} L_{\mathrm{III}}{ }^{-}$edge XAS data was performed on B18 at the Diamond Light Source, UK (proposal No. SP17782).

\section{References}

Adam, N., Hinz, K., Gaona, X., Panak, P. J. \& Altmaier, M. (2021). Radiochim. Acta, 109, 431-443.

Aimoz, L., Wieland, E., Taviot-Guého, C., Dähn, R., Vespa, M. \& Churakov, S. V. (2012). Environ. Sci. Technol. 46, 3874-3881.

Batchelor, B. (2006). Waste Manage. (Oxford), 26, 689-698.

Bearden, J. A. \& Burr, A. F. (1967). Rev. Mod. Phys. 39, 125-142.

Bokhimi, X., Toledo-Antonio, J. A., Guzmán-Castillo, M. L. \& Hernández-Beltrán, F. (2001). J. Solid State Chem. 159, 32-40.

Bullard, J. W., Jennings, H. M., Livingston, R. A., Nonat, A., Scherer, G. W., Schweitzer, J. S., Scrivener, K. L. \& Thomas, J. J. (2011). Cem. Concr. Res. 41, 1208-1223.

Burns, P. C. \& Li, Y. (2002). Am. Mineral. 87, 550-557.

Çevirim-Papaioannou, N., Yalçıntaş, E., Gaona, X., Altmaier, M. \& Geckeis, H. (2018). Appl. Geochem. 98, 237-246.

Clark, S. M., Colas, B., Kunz, M., Speziale, S. \& Monteiro, P. J. M. (2008). Cem. Concr. Res. 38, 19-26.

Coda, A., Della Giusta, A. \& Tazzoli, V. (1981). Acta Cryst. B37, 1496-1500.
Colmenero, F., Fernández, A. M., Timón, V. \& Cobos, J. (2018). RSC Adv. 8, 24599-24616.

Dean, N. E., Hancock, R. D., Cahill, C. L. \& Frisch, M. (2008). Inorg. Chem. 47, 2000-2010.

Diaz-Moreno, S., Amboage, M., Basham, M., Boada, R., Bricknell, N. E., Cibin, G., Cobb, T. M., Filik, J., Freeman, A., Geraki, K., Gianolio, D., Hayama, S., Ignatyev, K., Keenan, L., Mikulska, I., Mosselmans, J. F. W., Mudd, J. J. \& Parry, S. A. (2018). J. Synchrotron Rad. 25, 998-1009.

Ding, W. (2017). Thesis, University of Leeds, UK.

Ding, W., Botha, J. A., Hanson, B. C. \& Burke, I. T. (2016). J. Alloys Compd. 688, 260-269.

Felipe-Sotelo, M., Hinchliff, J., Field, L. P., Milodowski, A. E., Preedy, O. \& Read, D. (2017). Chemosphere, 179, 127-138.

Finch, R. J. \& Ewing, R. C. (1997). Am. Mineral. 82, 607-619.

Goetz-Neunhoeffer, F. \& Neubauer, J. (2006). Powder Diffr. 21, 4-11.

Goetz-Neunhoeffer, F., Neubauer, J. \& Schwesig, P. (2006). Cem. Concr. Res. 36, 65-70.

Greaux, S., Gautron, L., Andrault, D., Bolfan-Casanova, N., Guignot, N. \& Haines, J. (2008). Am. Mineral. 93, 1090-1098.

Harfouche, M., Wieland, E., Dähn, R., Fujita, T., Tits, J., Kunz, D. \& Tsukamoto, M. (2006). J. Colloid Interface Sci. 303, 195-204.

Hewlett, P. C. \& Liska, M. L. (2019). Lea's Chemistry of Cement and Concrete, 5th ed. Oxford: Butterworth-Heinemann.

Ke, X., Bernal, S. A. \& Provis, J. L. (2017). Cem. Concr. Res. 100, $1-13$.

Klingensmith, A. L., Deely, K. M., Kinman, W. S., Kelly, V. \& Burns, P. C. (2007). Am. Mineral. 92, 662-669.

Lothenbach, B., Scrivener, K. \& Hooton, R. D. (2011). Cem. Concr. Res. 41, 1244-1256.

Marcus, Y. (1988). Chem. Rev. 88, 1475-1498.

Marcus, Y. (2012). J. Chem. Phys. 137, 154501.

Mayer, H. \& Mereiter, K. (1986). TMPM Tschermaks Petr. Mitt. 35, 133-146.

McMurdie, H., Morris, M., Evans, E., Paretzkin, B., Wong-Ng, W. \& Hubbard, C. (1986). Powder Diffr. 1, 267.

Morris, M. C., McMurdie, H. F., Evans, E. H., Paretzkin, B., Hubbard, C. R. \& Carmel, S. J. (1980). Standard X-ray Diffraction Powder Patterns, Section 17, Data for 58 Substances, p. 16. Gaithersburg: National Bureau of Standards.

Nuclear Decommissioning Authority (2013). Packaging of Plutonium Contaminated Material at the Waste Treatment Complex (Extension to Final stage and Periodic Review).

Nuclear Decommissioning Authority (2014). Report 21083362 Uranics, Credible Options Summary (Gate A).

Nuclear Decommissioning Authority (2019). 2019 UK Radioactive Waste Detailed Data.

Ojovan, M. I. \& Lee, W. E. (2005). An Introduction to Nuclear Waste Immobilisation, pp. 179-200. Elsevier.

Pshinko, G. N., Kosorukov, A. A., Puzyrnaya, L. N. \& Kobets, S. A. (2013). Radiochemistry, 55, 601-604.

Radha, A. V., Kamath, P. V. \& Shivakumara, C. (2007). Acta Cryst. B63, 243-250.

Radioactive Waste Management (2016). Report NDA/RWM/142. Geological Disposal. Investigating the Implications of Managing Depleted, Natural and Low Enriched Uranium through Geological Disposal.

Ravel, B. \& Newville, M. (2005). J. Synchrotron Rad. 12, 537-541.

Richardson, I. G. \& Groves, G. W. (1992). J. Mater. Sci. 27, 6204-6212.

Saslow, S. A., Kerisit, S. N., Varga, T., Mergelsberg, S. T., Corkhill, C. L., Snyder, M. M. V., Avalos, N. M., Yorkshire, A. S., Bailey, D. J., Crum, J. \& Asmussen, R. M. (2020). Environ. Sci. Technol. 54, 13610-13618.

Sideris, P. J., Blanc, F., Gan, Z. \& Grey, C. P. (2012). Chem. Mater. 24, 2449-2461.

Skibsted, J., Henderson, E. \& Jakobsen, H. J. (1993). Inorg. Chem. 32, 1013-1027. 
Skibsted, J., Pedersen, M. T. \& Holzinger, J. (2017). J. Phys. Chem. C, 121, 4011-4017.

Sutton, M., Warwick, P. \& Hall, A. (2003). J. Environ. Monit. 5, $922-$ 928.

Takahashi, K., Fujino, T. \& Morss, L. R. (1993). J. Solid State Chem. 105, 234-246.

Taylor, H. F. W. (1973). Mineral. Mag. 39, 377-389.

Thompson, H. A., Brown, G. E. Jr \& Parks, G. A. (1997). Am. Mineral. 82, 483-496.

Valsami-Jones, E. \& Ragnarsdöttir, K. V. (1997). Radiochim. Acta, 79, 249-258.

Veelen, A. van, Copping, R., Law, G. T. W., Smith, A. J., Bargar, J. R., Rogers, J., Shuh, D. K. \& Wogelius, R. A. (2018). Mineral. Mag. 76, 3095-3104.

Walkley, B. \& Provis, J. L. (2019). Materials Today Advances, 1, 100007.
Walling, S. A., Bernal, S. A., Kinoshita, H., Collier, N. C. \& Provis, J. L. (2014). Adv. Appl. Ceram. 113, 496-501.

Wieland, E., Macé, N., Dähn, R., Kunz, D. \& Tits, J. (2010). J. Radioanal. Nucl. Chem. 286, 793-800.

Wijitwongwan, R., Intasa-ard, S. \& Ogawa, M. (2019). ChemEngineering, 3, 68 .

Yalçıntaş, E., Çevirim-Papaioannou, N., Gaona, X., Fellhauer, D., Neck, V. \& Altmaier, M. (2019). J. Chem. Thermodyn. 131, 375386.

Yang, D. Y. \& Guo, R. (2014). Exp. Tech. 38, 6-12.

Yorkshire, A. S. (2020). Thesis, Univeristy of Sheffield, UK.

Zachariasen, W. H. (1954). Acta Cryst. 7, 788-791.

Zhou, Q., Milestone, N. B. \& Hayes, M. (2006). J. Hazard. Mater. 136, 120-129. 